[DOI: 10.24214/jecet.A.8.1.05271.]

Jaurnal of Environmental Science, Computer Science and Engineering \& Technology

An International Peer Review E-3 Journal of Sciences and Technology

Available online at www.jecet.org

Section A: Environmental Science

Research Article

\title{
Genetic link between HFSE - Base and Precious metals in Mylonite and N-S Lamprophyre Dikes, Abu Rusheid Area, Egypt
}

\author{
Mohamed El-Ahmady Ibrahim and Mohamed Salem Kamar \\ Nuclear Materials Authority, P.O. Box: 530, Maadi, Cairo, Egypt
}

Received: 04 December 2018; Revised: 08January 2019; Accepted: 12 January 2019

\begin{abstract}
Abu Rusheid area is located at the southern Eastern Desert of Egypt and regarding as closed basin. The ophiolitic metagabbro forms the higher peripheral parts of the basin and thrusted over the ophiolitic mélange. The banded cataclastic rocks (NNW-SSE, 30 $/ \mathrm{WSW}$ ) were deposited in the central part of basin and subdivided from base to top into; protomylonites, mylonites, ultramylonites and quartzite. They are subjected to regional metamorphism (sillmanite- kaynite - garnet facies) and cut by two shear zones (N-S and E-W trends). The shear zones are intruded by discontinuous and brecciate lamprophyre dikes. The cataclastic rocks were subjected to hydrothermal alteration types, including propylitic, sericitic, Na-metasomatism, ferrugination, fluoritization, and argillation, whereas lamprophyre dikes were underwent ferrugination, kaolinitization, sericitization, and calcification. The mylonites and N-S lamprophyre dikes, are extremely rich in base metals $(\mathrm{Pb}, \mathrm{Zn}, \mathrm{Cu}$, and $\mathrm{As})$, precious metals (Au and Ag) and HFSE (Nb, U, Zr, HREE and Y). They show MREY > HREY $>$ LREY. The HREEs minerals are represented by xenotime, fergusonite, fluorite and zircon. The average of U/Th ratio in mylonites and lamprophyre dikes $(1.3-40.0)$ is higher than protomylonites and ultramylonites $(0.24)$ manifesting migration in and out respectively. Ascending and descending hydrothermal solutions are affected on the Abu Rusheid rocks. These solutions with low temperatures and containing $\mathrm{F}^{1}$ - and $\mathrm{CO}_{3}{ }^{2}-, \mathrm{PO}_{4}{ }^{3}-$ and $\mathrm{H}_{2} \mathrm{O}$ caused redistribution; transportation and redeposition of the base metals, precious metals and HFSE from the mylonite rocks through channel ways to lamprophyre dikes, in addition to the clay minerals and carbonates were formed.
\end{abstract}


Keywords: Mylonite, Lamprophyre, REE, Precious metals, Uranium, Abu Rusheid.

\section{INTRODUCTION}

Uranium and associated rare metals exploration works in Nuclear Materials Authority (NMA) could be distinguished into two main stages: 1-Before 1996, the exploration works resulted in the discovery of some low grade U- occurrences which related to various geologic environments at the Eastern Desert and Sinai such as; shear zones in calc-alkaline granite and inter-mountain basin Gabel (G.) Gattar, veintype (G. El-Missikat), metasomatised granite (G. Um Ara), and surficial type U-deposit in sedimentary rocks (Abu Zeneima, Sinai).2- After 1996, NMA exploration activities for uranium and rare metals resources were focusing on the south Eastern Desert of Egypt. These works resulted in the discovery of three U- resources .The latter (from south to north) includes vein-type (G. El-Sela, Abu Ramad area), metamorphosed cataclastic rocks and associated lamprophyre dikes at Abu Rusheid area, and metamorphosed sandstone-type uranium deposited at Wadi Sikait.It is worthy to mention that, the development of the above prospects based on regional, semi-detailed and detailed remote sensing, airborne, geological, geochemical and geophysical exploration, supported by a limited amount of exploration drilling (cores and trenches).

Abu Rusheid area is enrichment in various economic mineralization (e.g. Be, Nb, Th, and U), that make this area as one of the most important and promising areas for different authors ${ }^{1-10}$. The geology, geochemistry and mineralogy of the cataclastic rocks and associated lamprophyre dikes at Abu Rusheid area were attracted many workers ${ }^{11-19}$. Twenty one representative samples from mylonite and seven samples from protomylonite and ultramylonite were measured. Twelve samples (12) from N-S lamprophyre dikes after ${ }^{15-18}$ were used to illustrate the genetic link between HREEs, $\mathrm{U}, \mathrm{Zn}, \mathrm{Pb}, \mathrm{Cu}, \mathrm{Nb}$ Ta and Au-Ag mineralization in mylonite and N-S lamprophyre dikes at Abu Rusheid area.

\section{GEOLOGIC SETTING}

The Abu Rusheid area lies in the southern part of the Eastern Desert of Egypt (SED)(Figs.1\&2). The geologic setting for the exposed rocks of Abu Rusheid area was arranged from the oldest to the youngest according to ${ }^{11,12}$ as follows (a) ophiolitic metagabbro, (b) ophiolitic mélange, consisting of ultramafic and layered metagabbro set in metasediment matrix, (c) cataclastic rocks, (d) Late- to Post-orogenic granitic rocks which were latter intruded by (e) lamprophyre dikes, pegmatite segregation and quartz veins (Fig.1).

2.a-The ophiolitic rocks are comprises ophiolitic dismembers assemblage of mountainous size (serpentinites and metagabbros) form fold thrust sheets around Wadi Sikait and Wadi Abu Rusheid and thrusted over ophiolitic mélange (WNW-ESE and dips $33^{\circ} / \mathrm{NNE}$ ). The latter is composed mainly of rock fragments (amphibolite sheets, metagabbros masses, allocthonous serpentinite and related talc carbonate) embedded in fine-grained matrix of quartzo-feldspathic schist, sillmanite schist and garnetiferous biotite schist.

2.b- The cataclastic rocks (Fig.1) are light grey to grey in color, fine to coarse-grained, banded and display layering (Fig.2). They cover an area of about $2 \mathrm{~km}^{2}$ and represented from the base, by protomylonite, mylonite, ultramylonite, and silicified ultramylonite(quartzite, at top) with gradational contacts and cut by two shear zones generally(N-S and E-W trend).The cataclastics exhibit alteration, including albitization, kaolinitization, chloritization, fluoritization, and hematitization ${ }^{13}$. The shear zones range from 2 to $10 \mathrm{~m}$ in width and $400-1500 \mathrm{~m}$ in length with vertical dip and extruded by 
lamprophyre dikes. The latter are good physical and chemical ${ }^{18}$ trap for $\mathrm{U}, \mathrm{REEs}, \mathrm{Cu}, \mathrm{Zn}, \mathrm{Ag}, \mathrm{Pb}$ and $\mathrm{Y}$.

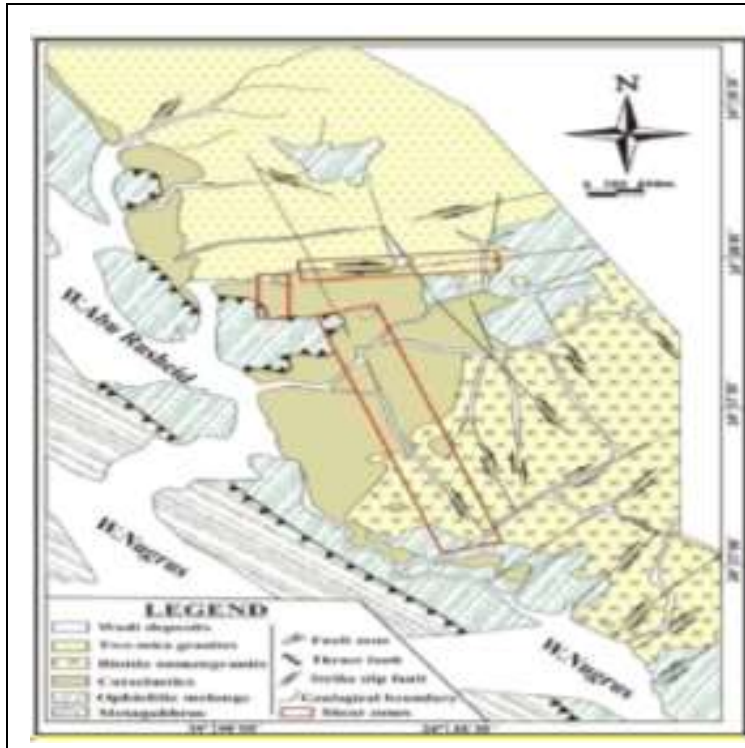

Fig. (1a): Regional geologic map of Abu Rusheid area, showing shear zones after ${ }^{17}$

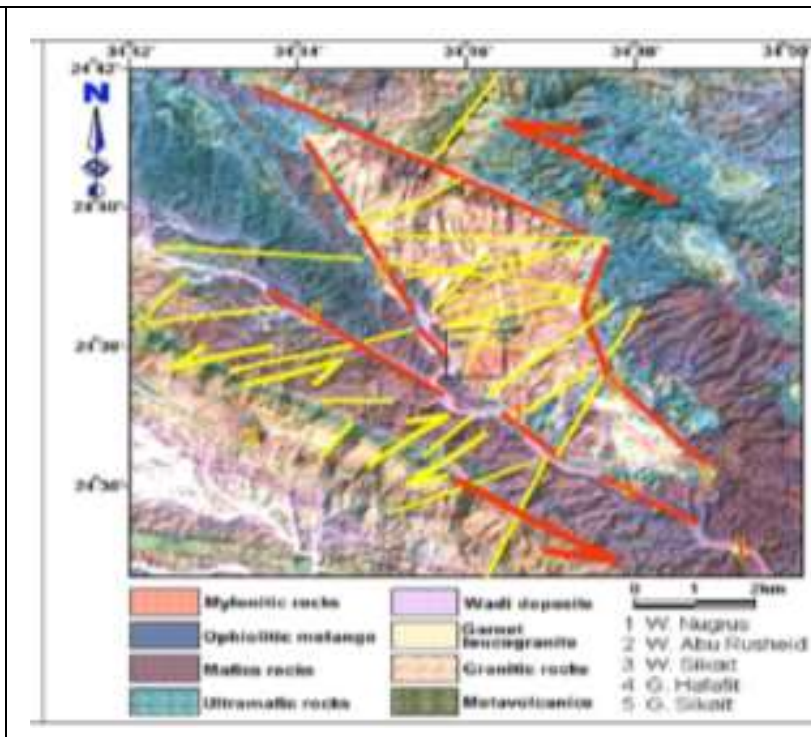

Fig. (1b): Simplified landsat image showing the regional structural, Abu Rusheid, after ${ }^{13,20}$.

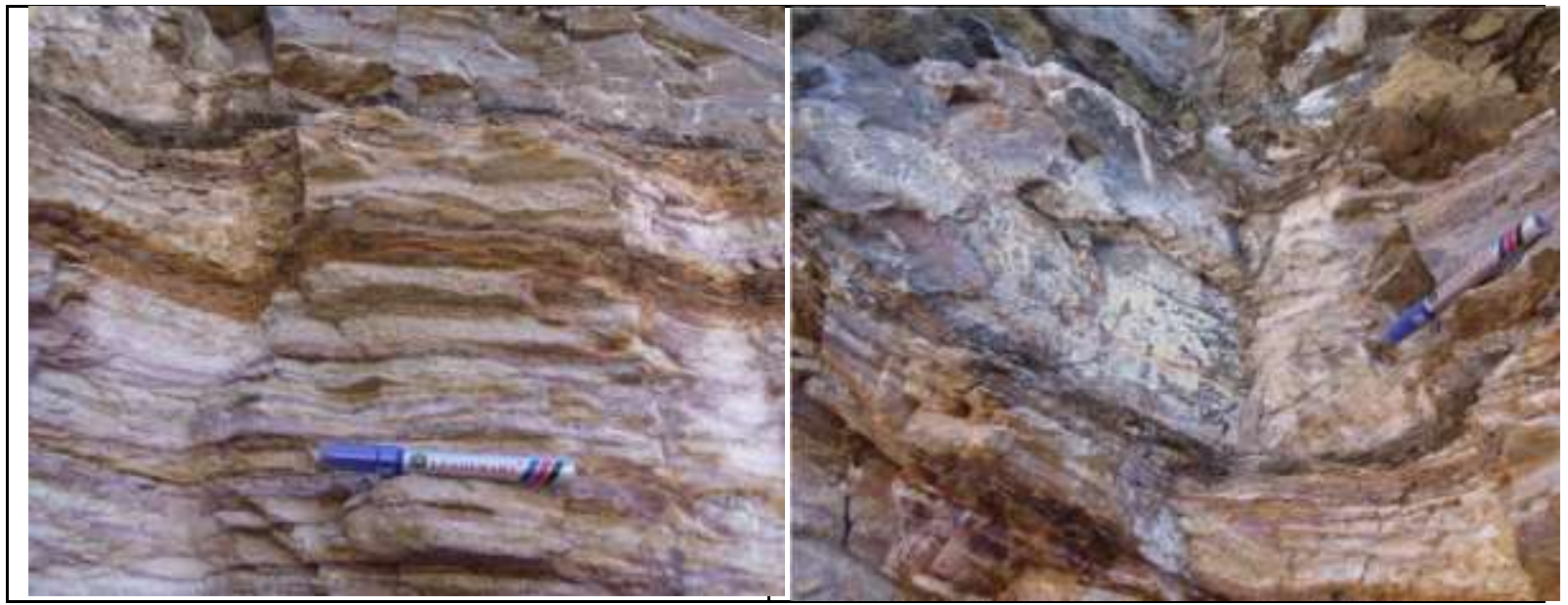

Fig.(2): Field photographs showing banded and layered mylonite (NNW-SSE trend, dips $10^{0}-30^{\circ} / \mathrm{WSW}$ ), Abu Rusheid area.

The protomylonite is coarse to very -coarse grained, green to dark greenish grey in color, crops out eastward flank of Wadi Abu Rusheid, covering about 12.0 in vol. \% of the cataclastics ${ }^{12,14}$. The rocks are banded (NNW-SSE), dipping $30^{\circ} / \mathrm{WSW}$, with frequent occurrence of greenish-microcline veinlets running parallel to the banding planes (amazonite, $1-2 \mathrm{~cm}$ in length and $0.5 \mathrm{in}$ width). The protomylonite is composed mainly of k-feldspars, quartz, plagioclase and biotite flakes. Zircon, allanite, apatite and opaque are accessories, while muscovite, kaolinite and chlorite are secondary minerals.

The Mylonite is fine to medium- grained and well banded (NNW- SSE and dips $10 \%$ WSW) covering a large area representing 65.0 in vol. $\%$ of the cataclastic rocks with low to medium relief ${ }^{13}$. These rocks are intercalated with protomylonite and affected by weathering in a variable degrees producing 
red to yellow colors due to the alteration of sulfides producing iron oxides (hematite-limonite).They show bedding-parallel digenetic foliations defined by elongate detrital pre-tectonic augen quartz in mylonite and idioblastic garnet (Fig.3).Microscopically, the mylonite is composed mainly of quartz, kfeldspars, plagioclases, zinnwaldite, muscovite, biotite and kaynite (Fig.4). Zircon, allanite, apatite, fluorite, garnet, fergusonite, xenotime and opaque are accessories. Kaolinite and epidote are secondary minerals.

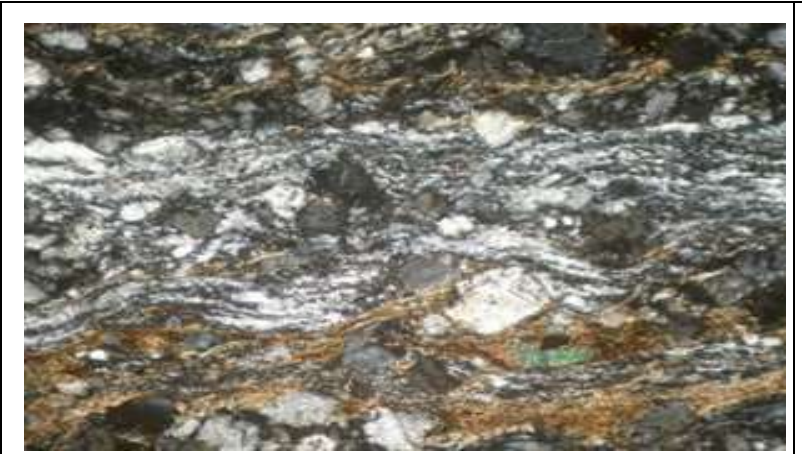

Fig. (3): View showing bedding-parallel digenetic foliations defined by elongate detrital pretectonic augen quartz in mylonite and idioblastic garnet.

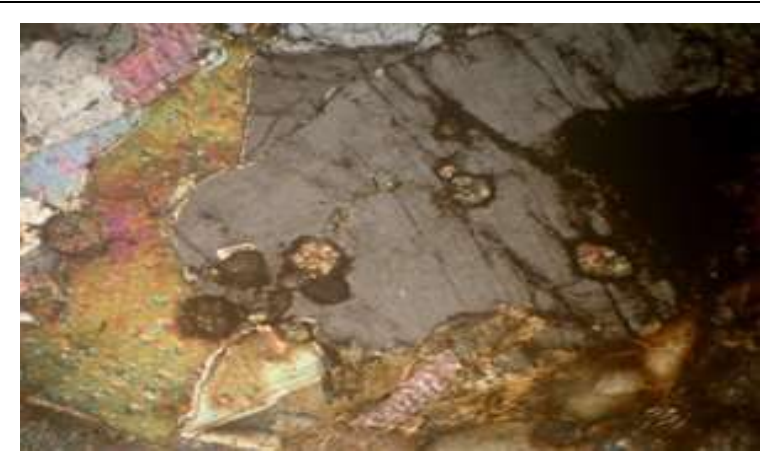

Fig. (4): Fine crystals of zircon included in kaynite crystal (Ky) surrounded by biotite, (C.N., $X=20$ ) after $^{19}$.

The ultramylonite is light grey to grey in color, fine to medium grained and exhibits both banding and augen structures covering about $17.0 \%$ of the cataclastic rocks. Some pyrite crystals were removed leaving vugs filled with quartz, carbonates and yellow U- minerals. Columbite-tantalite occurs abundantly as disseminated minute grains either as single crystal or aggregates, visible by naked eyes ${ }^{13,14}$. Microscopically, they are composed of quartz, $\mathrm{k}$-feldspars, plagioclase, biotite, muscovite and sillimanite (Fig.5a) embedded in cryptocrystalline groundmass. Zircon, garnet (Fig.5b), allanite, xenotime and opaque are accessories. Kaolinite and epidote are the common alteration products.
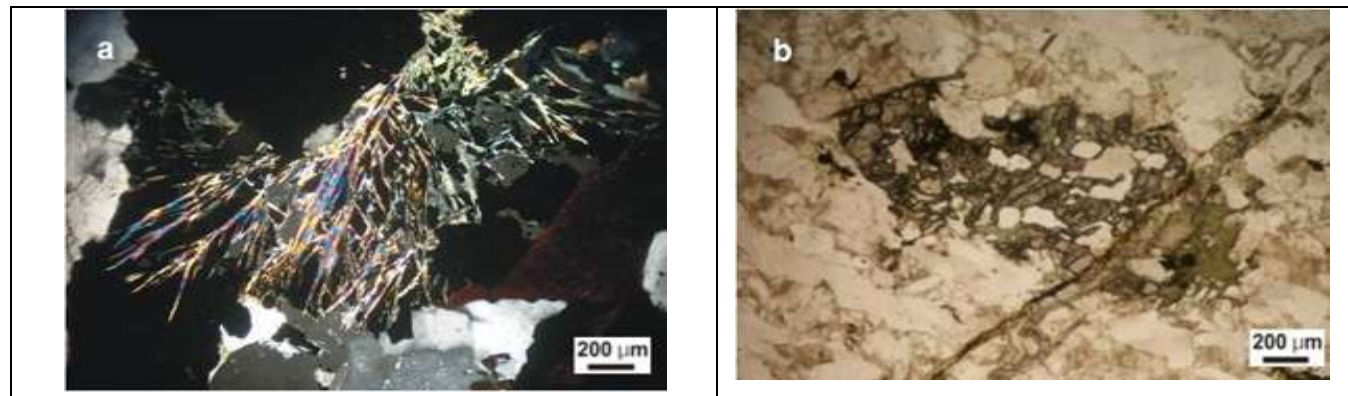

Fig. (5): View in ultramylonite drill core sample showing (a) fibrous sillimanite and (b) garnet porphyroclast contains quartz and chlorite inclusions at depth $38.6 \mathrm{~m}$. After ${ }^{15}$

The quartzite covers about $6.0 \%$ of the cataclastics with irregular and oval shape $(5-20 \mathrm{~m})$ overlie all the previous cataclastic rocks ${ }^{13}$. Sulfides are dominantly pyrite, arsenopyrite, with rare galena impregnations along fractures and cleavage planes of other minerals. Smoky quartz is the dominant mineral in the quartzite (85- 95 in vol. \%). The quartzite rocks are depleted in rare metals $(\mathrm{U}, \mathrm{Nb}, \mathrm{Zr}$ and $\mathrm{Th}$ ) compared with the other cataclastic varieties ${ }^{12}$. Microscopically, the silicified ultramylonite (quartzite) is mainly composed of quartz $\left(\mathrm{SiO}_{2}=90\right.$ in vol. \%) with relatively rare plagioclase, kfeldspars and biotite. Zircon, fluorite and opaque are accessory minerals.

2. c-Lamprophyre dikes: The cataclastic rocks of the Abu Rusheid area cut by three shear zones in N$\mathrm{S}$ (Figs.6\&7) and E-W trends. The two shear zones (N-S trend) are intruded by discontinuous and 
brecciate lamprophyre dikes (L1 and L2). The lamprophyre dikes range from $0.5-1.0 \mathrm{~m}$ in width, 0.4$1.5 \mathrm{~km}$ in length. These lamprophyre dikes are characterized by variable colors (black, whitish, pink, and red) depending on the degree of alterations (kaolinitization, ferrugination, carbonitization, fluoritization, hematitization, and sericitization).The feldspars and micas in lamprophyres are partially altered to clay minerals (chemical traps) while the oxidation of sulfide minerals left ocelli (physical traps), usually filled by calcite and U- minerals ${ }^{18}$.

Microscopically, they are mainly composed of plagioclases, amphiboles, phlogopite, and relics of pyroxenes phenocrysts embedded in a fine-grained groundmass. Xenotime, fluorite, chlorite, and opaque are accessories. Carbonate, quartz, jarosite, pyrite, epidote, and clay minerals are secondary minerals. Most of feldspars and micas are altered.

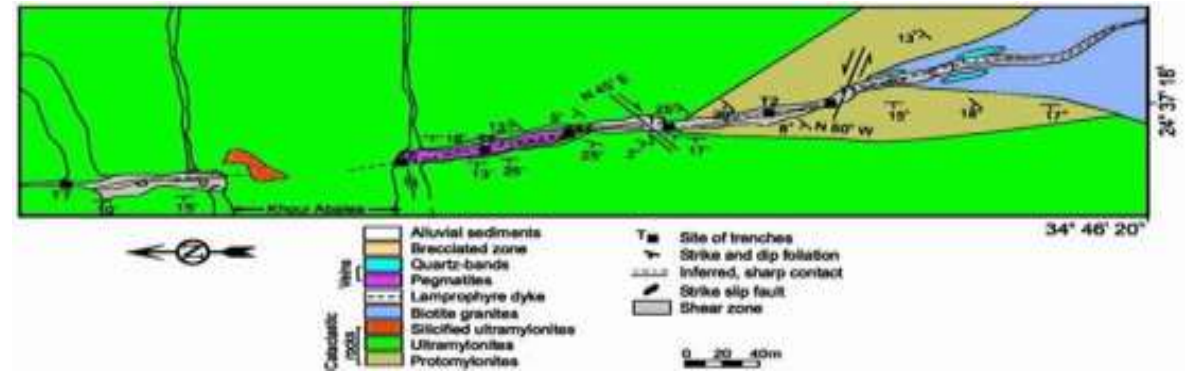

Fig. (6): Detailed geologic map of N-S lamprophyre dike (L1), Abu Rusheid area, after ${ }^{13}$

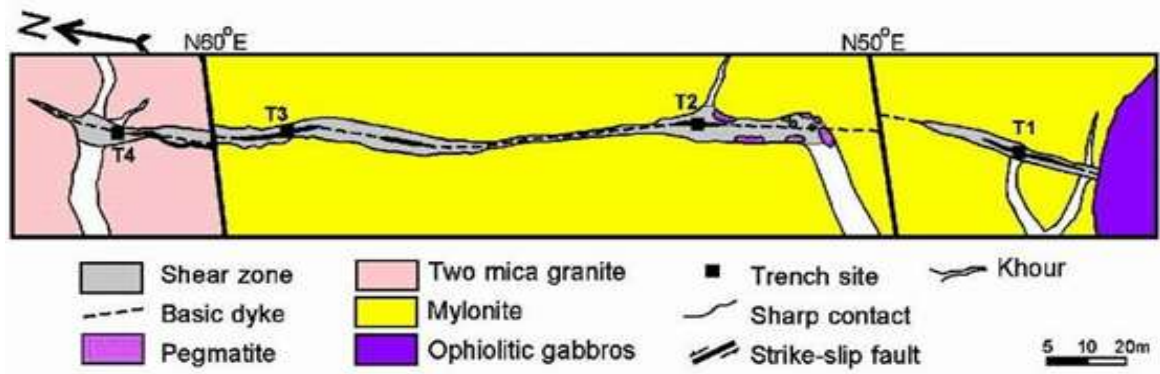

Fig. (7): Detailed geologic map of N-S lamprophyre dike (L2), Abu Rusheid area after ${ }^{13}$

\section{METHODOLOGY}

Twenty one representative samples from mylonite and seven samples from protomylonite and ultramylonite were measured at ACME Labs of Vancouver in Canada using the inductively coupled plasma mass spectrometry (ICP-MS) techniques, Vancouver, Canada. The major elements, and the trace elements $\mathrm{Cr}, \mathrm{Zr}, \mathrm{Nb}, \mathrm{Mo}, \mathrm{Cu}, \mathrm{Pb}, \mathrm{Zn}$ and $\mathrm{Ni}$ were determined by ICP-ES, while the elements, $\mathrm{Ba}, \mathrm{Co}$, $\mathrm{Cs}, \mathrm{Ga}, \mathrm{Hf}, \mathrm{Nb}, \mathrm{Rb}, \mathrm{Ta}, \mathrm{Th}, \mathrm{U}, \mathrm{V}, \mathrm{Zr}, \mathrm{Y}$ and REE were analyzed by ICP-MS. The results of major oxides, trace elements and rare earth elements data are given in Tables (2\&3).Mineralogical studies were carried out from samples which have been separated by heavy liquid(bromoform). The heavy fractions were subjected to the magnetic separation using a Frantz isodynamic magnetic separator (model LB 1). The minerals of interest were picked up under a binocular microscope to obtain monomineralic fraction for identification and analysis. The identification was carried out by XRD and the environmental scanning electron-microscope (ESEM; model PhilipsXL30)at the laboratories of the Nuclear Materials Authority of Egypt (NMA), supported by an energy-dispersive spectrometry (EDS) unit which was used at $25-30 \mathrm{kV}$ accelerating voltage, 1-2 mm beam diameter, and 60-120 s counting time. 


\section{MINERALOGY}

Uranium minerals [(uranophane $\left(\mathrm{CaO} .2 \mathrm{UO}_{3} \cdot 2 \mathrm{SiO}_{2} \cdot 6 \mathrm{H}_{2} \mathrm{O}\right)$, autunite and meta-autunite $\left(\mathrm{Ca}\left(\mathrm{UO}_{2}\right) 2\left(\mathrm{PO}_{4}\right) 2.8-\mathrm{H}_{2} \mathrm{O}\right)$, kasolite $\mathrm{Pb}\left(\mathrm{UO}_{2}\right)(\mathrm{SiO} 3)(\mathrm{OH}) 2$, torbernite $\left.\mathrm{Cu}\left(\mathrm{UO}_{2}\right) 2\left(\mathrm{PO}_{4}\right) 2.8-12 \mathrm{H}_{2} \mathrm{O}\right]$, meta-zeunerite $\mathrm{Cu}\left(\mathrm{UO}_{2}\right) 2\left(\mathrm{AsO}_{4}\right) 2 \cdot 8 \mathrm{H}_{2} \mathrm{O}$ and soddyite $\left(\mathrm{UO}_{2}\right) 2 \mathrm{SiO}_{4}\left(\mathrm{H}_{2} \mathrm{O}\right)_{2}$ were reported by ${ }^{11.13 .18 .19}$. in both cataclastic rocks (quartzite excluded) and lamprophyre dikes (Table1).

Thorite and uranothorite were recorded in cataclastic rocks only (mylonite, protomylonites and ultramylonite). Precious metals ( $\mathrm{Au}$ and $\mathrm{Ag}$ ) were record in mylonite and lamprophyre dikes, furthermore, HREEs, Li and As were investigate in mylonite for the first time in the present study. The separated minerals from the lamprophyre samples include visible U-minerals (uranophane, kasolite, autunite and torbernite), silver, Mn-frankilinite, woodruffite, xenotime, fluorite and scheelite ${ }^{13,18}$ Ferrugination is represented by hematite, limonite and goethite. Precious metals (gold and silver) are associated with pyrite, sphalerite, chalcopyrite and bismothinite (Table1) in mylonite and lamprophyres.The mylonite rocks and lamprophyre dikes are rich in zircon, fluorite columbite, and xenotime.

Table 1: Results of the recorded minerals in cataclastics rocks and lamprophyre dikes modified $\operatorname{after}^{15,16,18,19 .}$

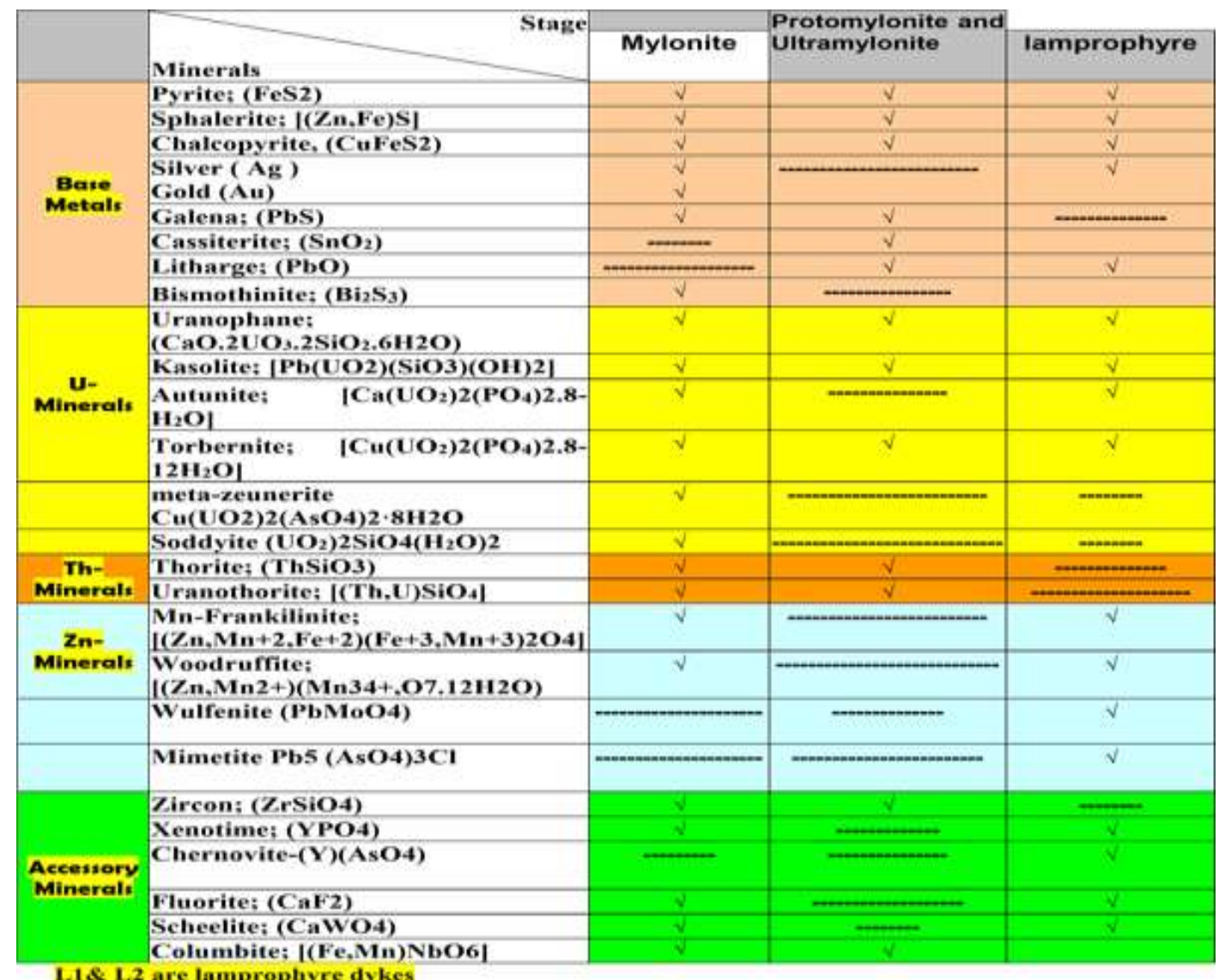

L.1\& 1,2 are lamprophyre dykes 
Table 2: Major oxides (wt \%) , trace elements and REEs (in ppm) of mylonite, Abu Rusheid area.

\begin{tabular}{|c|c|c|c|c|c|c|c|c|c|c|c|}
\hline $\begin{array}{c}\text { Oxides } \\
(\%)\end{array}$ & $\mathrm{SiO}_{2}$ & $\mathrm{TiO}_{2}$ & $\mathbf{A l}_{2} \mathbf{O}_{3}$ & $\mathrm{Fe}_{2} \mathrm{O}_{3}$ & MgO & MnO & $\mathrm{CaO}$ & $\mathrm{Na}_{2} \mathrm{O}$ & $\mathbf{K}_{2} \mathrm{O}$ & $\mathbf{P}_{2} \mathbf{O}_{5}$ & Total \\
\hline EG2 & 80.41 & 0.02 & 8.18 & 5.82 & 0.08 & 0.35 & 0.99 & 0.68 & 3.45 & 0.02 & 100 \\
\hline EG3 & 69.96 & 0.04 & 12.39 & 10.09 & 0.17 & 0.6 & 1.44 & 0.28 & 5.01 & 0.02 & 100 \\
\hline EG4 & 74.01 & 0.01 & 13.85 & 5.09 & 0.08 & 0.23 & 0.13 & 3.44 & 3.13 & 0.02 & 99.99 \\
\hline EG5 & 71.56 & 0.03 & 13.66 & 6.02 & 0.36 & 0.18 & 0.88 & 5.86 & 1.43 & 0.01 & 99.99 \\
\hline EG7 & 75.01 & 0.03 & 12.83 & 2.69 & 0.03 & 0.12 & 0.24 & 5.7 & 3.34 & 0.01 & 100 \\
\hline EG8 & 74.59 & 0.03 & 12.55 & 3.03 & 0.05 & 0.15 & 0.34 & 5.49 & 3.76 & 0.02 & 100.01 \\
\hline EG9 & 76.89 & 0.01 & 3.82 & 11.55 & 0.07 & 0.04 & 5.02 & 2.25 & 0.33 & 0.03 & 100.01 \\
\hline EG13 & 74.17 & 0.02 & 13.11 & 2.59 & 0.05 & 0.13 & 0.18 & 5.25 & 4.48 & 0.01 & 99.99 \\
\hline EG16 & 75.77 & 0.03 & 12.64 & 2.52 & 0.17 & 0.74 & 0.41 & 4.65 & 3.07 & 0.01 & 100.01 \\
\hline EG17 & 75.2 & 0.03 & 13.09 & 2.14 & 0.08 & 0.55 & 0.21 & 5.35 & 3.34 & 0.01 & 100 \\
\hline EG23 & 75.77 & 0.02 & 12.24 & 2.59 & 0.05 & 0.02 & 0.22 & 5.59 & 3.48 & 0.01 & 99.99 \\
\hline EG25 & 72.76 & 0.13 & 15.06 & 3.43 & 0.1 & 0.03 & 0.32 & 5.98 & 2.18 & 0.01 & 100 \\
\hline EG26 & 73.71 & 0.2 & 14.96 & 4.15 & 0.15 & 0.03 & 0.38 & 3.52 & 2.88 & 0.02 & 100 \\
\hline EG27 & 71.7 & 0.23 & 14.98 & 5.73 & 0.13 & 0.27 & 0.48 & 2.14 & 4.34 & 0.01 & 100.01 \\
\hline EG29 & 73.47 & 0.03 & 13.89 & 2.65 & 0.05 & 0.21 & 0.1 & 5.38 & 4.22 & 0.01 & 100.01 \\
\hline EG31 & 75.7 & 0.02 & 13.64 & 3.86 & 0.05 & 0.31 & 0.14 & 2.35 & 3.89 & 0.03 & 99.99 \\
\hline EG32 & 77.83 & 0.01 & 11.68 & 3.95 & 0.03 & 0.31 & 0.13 & 2.71 & 3.32 & 0.04 & 100.01 \\
\hline EG33 & 77.12 & 0.01 & 12.83 & 1.66 & 0.07 & 0.14 & 0.15 & 6.2 & 1.81 & 0.01 & 100 \\
\hline EG35 & 76.62 & 0.02 & 11.88 & 1.76 & 0.02 & 0.07 & 0.53 & 6.1 & 3 & 0.002 & 100.002 \\
\hline EG36 & 68.72 & 0.03 & 15.81 & 6 & 0.03 & 0.1 & 0.31 & 5.78 & 3.2 & 0.01 & 99.99 \\
\hline EG48 & 75.88 & 0.03 & 13.13 & 2.89 & 0.08 & 0.23 & 0.13 & 3.99 & 3.63 & 0.02 & 100.01 \\
\hline
\end{tabular}

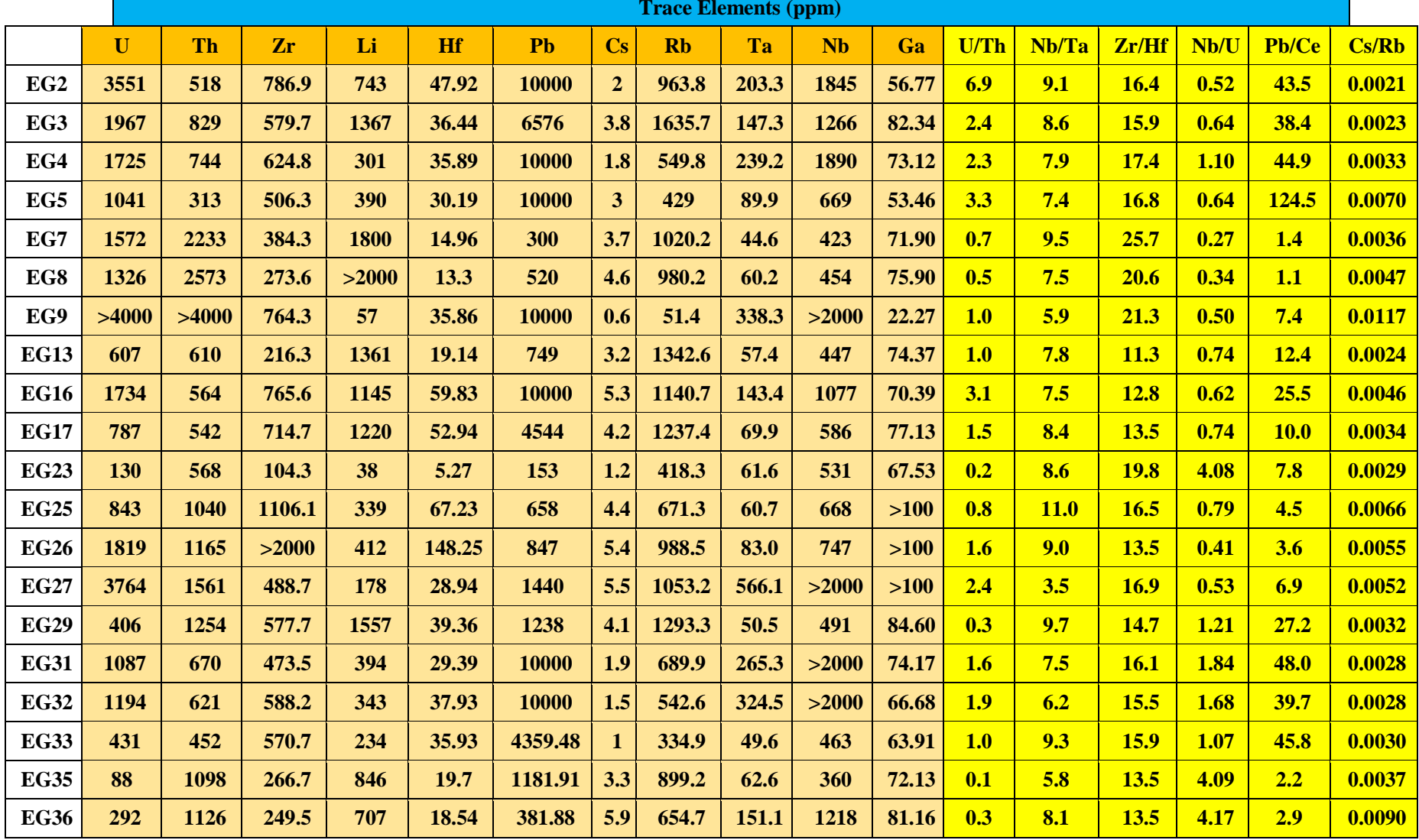


Genetic link...

Mohamed and Mohamed.

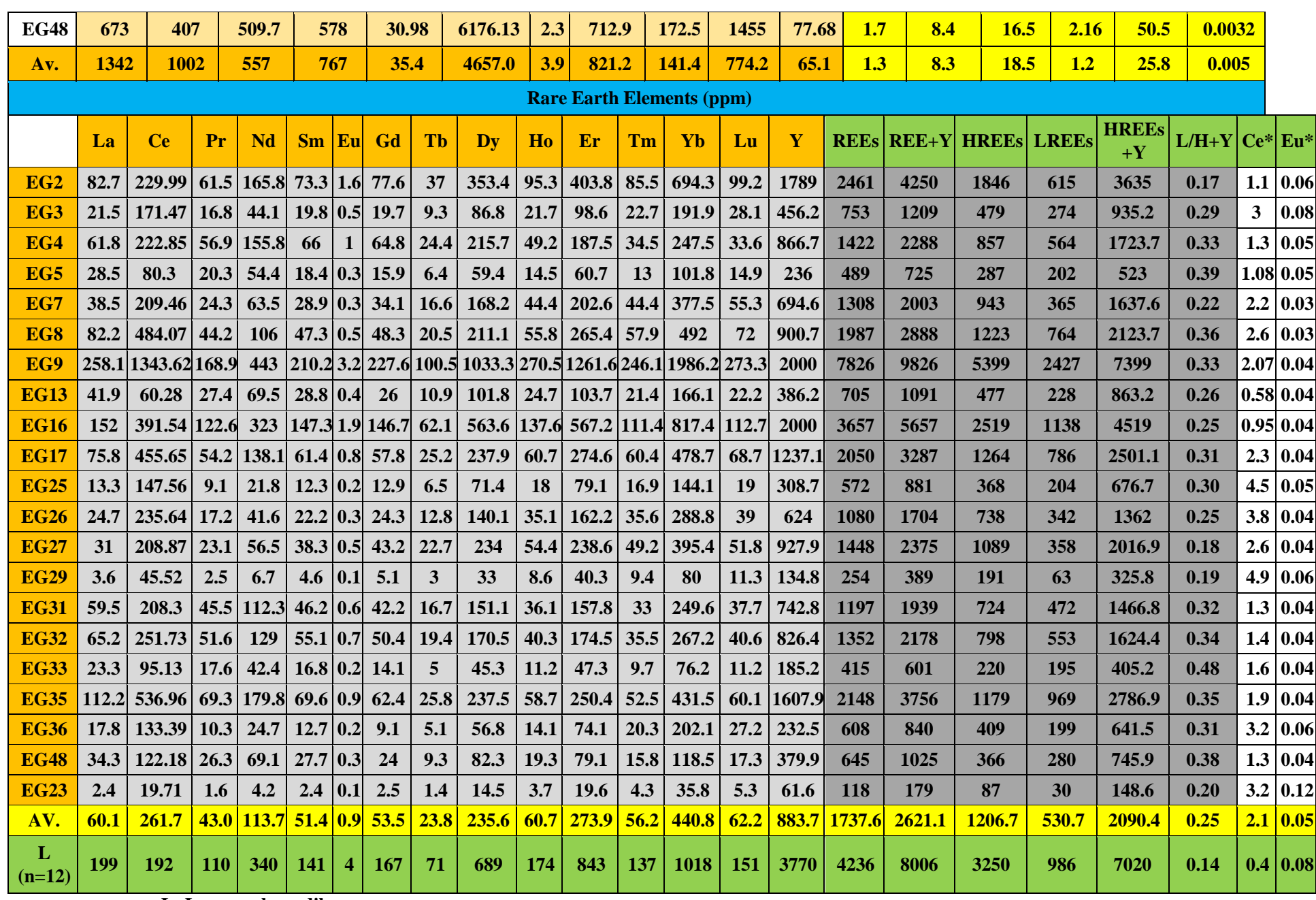

L: Lamprophyre dikes

Table 3: Major oxides (Wt. \%), trace elements and REEs (in ppm) of protomylonite and ultramylonite, Abu Rusheid area

\begin{tabular}{|c|c|c|c|c|c|c|c|c|}
\hline $\begin{array}{l}\text { Oxide } \\
(w t \%)\end{array}$ & EG10 & EG18 & EG19 & EG20 & EG30 & EG38 & EG40 & \\
\hline $\mathrm{SiO}_{2}$ & 76.45 & 72.35 & 71.2 & 70.33 & 75.48 & 69.39 & 71.16 & \\
\hline $\mathrm{TiO}_{2}$ & 0.03 & 0.02 & 0.03 & 0.03 & 0.02 & 0.03 & 0.34 & \\
\hline $\mathbf{A l}_{2} \mathbf{O}_{3}$ & 12.09 & 13.4 & 13.74 & 13.79 & 13 & 14.98 & 13.4 & \\
\hline $\mathrm{Fe}_{2} \mathrm{O}_{3}$ & 2.07 & 4.26 & 4.3 & 5.46 & 1.76 & 6.46 & 5.83 & \\
\hline MgO & 0.02 & 0.12 & 0.13 & 0.07 & 0.08 & 0.03 & 0.41 & \\
\hline MnO & 0.05 & 0.08 & 0.09 & 0.08 & 0.12 & 0.62 & 0.22 & \\
\hline $\mathrm{CaO}$ & 0.11 & 0.45 & 0.42 & 0.43 & 0.17 & 0.21 & 0.48 & \\
\hline $\mathrm{Na}_{2} \mathrm{O}$ & 6.29 & 7.39 & 8.02 & 6.53 & 5.87 & 3.97 & 3.35 & \\
\hline $\mathbf{K}_{2} \mathbf{O}$ & 2.88 & 1.87 & 1.99 & 3.22 & 3.51 & 4.29 & 4.79 & \\
\hline $\mathbf{P}_{2} \mathrm{O}_{5}$ & 0.01 & 0.08 & 0.07 & 0.06 & 0.005 & 0.02 & 0.03 & \\
\hline \multirow[t]{3}{*}{ Total } & 100 & 100.02 & 99.99 & 100 & 100.015 & 100 & 100.01 & \\
\hline & \multicolumn{7}{|c|}{ Trace Elements (ppm) } & \\
\hline & EG10 & EG18 & EG19 & EG20 & EG30 & EG38 & EG40 & Av. \\
\hline $\mathbf{U}$ & 196 & 145 & 139 & 47 & 603 & 302 & 135 & 223.9 \\
\hline Th & 153 & 1207 & 930 & 922 & 296 & 1745 & 1314 & 938.1 \\
\hline
\end{tabular}




\begin{tabular}{|c|c|c|c|c|c|c|c|c|}
\hline $\mathrm{Zr}$ & 625.1 & 375.6 & 239.3 & 185.8 & 464.3 & 212.2 & 131.8 & 319.2 \\
\hline $\mathbf{L i}$ & 1032 & $>2000$ & $>2000$ & 1549 & 931 & 491 & 885 & 977.6 \\
\hline Ta & 45.5 & 29.9 & 39.8 & 18.9 & 48.9 & 98 & 17.3 & 42.6 \\
\hline Hf & 31.43 & 13.94 & 9.24 & 6.71 & 34.83 & 12.29 & 4.8 & 16.2 \\
\hline $\mathbf{P b}$ & 118 & 207 & 271 & 203 & 1209 & 6180.87 & 2558.99 & 1535.4 \\
\hline Cs & 3.2 & 3.7 & 4.1 & 5.1 & 2.5 & 3.5 & 6.5 & 4.1 \\
\hline $\mathbf{R b}$ & 841.6 & 327.5 & 360.2 & 435.6 & 984.5 & 837 & 1124.1 & 701.5 \\
\hline $\mathbf{N b}$ & 414 & 295 & 366 & 246 & 415 & 880 & 144 & 394.3 \\
\hline $\mathbf{G a}$ & 78.49 & 82.55 & 86.98 & 77.48 & 71.02 & 68.68 & 46.02 & 73 \\
\hline U/Th & 1.3 & 0.1 & 0.1 & 0.1 & 2 & 0.2 & 0.1 & 0.6 \\
\hline $\mathrm{Nb} / \mathrm{Ta}$ & 9.1 & 9.9 & 9.2 & 13 & 8.5 & 9 & 8.3 & 9.6 \\
\hline $\mathrm{Pb} / \mathrm{Ce}$ & 1.2 & 0.4 & 0.5 & 0.4 & 13.2 & 3.1 & 12.3 & 4.4 \\
\hline $\mathrm{Cs} / \mathrm{Rb}$ & 0.0038 & 0.0113 & 0.0114 & 0.0117 & 0.0025 & 0.0042 & 0.0058 & 0.007 \\
\hline $\mathrm{Zr} / \mathrm{Hf}$ & 19.9 & 26.9 & 25.9 & 27.7 & 13.3 & 17.3 & 27.5 & 22.6 \\
\hline $\mathrm{Nb} / \mathrm{U}$ & 2.1 & 2 & 2.6 & 5.2 & 0.7 & 2.9 & 1.1 & 2.4 \\
\hline \multicolumn{8}{|c|}{ Rare Earth Elements } & Av. \\
\hline $\mathbf{L a}$ & 33.9 & 89.7 & 98.3 & 66.3 & 24.2 & 29.3 & 77.2 & 59.8 \\
\hline $\mathrm{Ce}$ & 96.53 & 486.45 & 554.4 & 543.36 & 91.45 & 2000 & 208.22 & 568.6 \\
\hline Pr & 14.3 & 52.1 & 52.6 & 35.7 & 17.3 & 24 & 24.1 & 31.4 \\
\hline Nd & 31.1 & 143.7 & 134.2 & 92.6 & 45.3 & 58.8 & 74.2 & 82.8 \\
\hline Sm & 10.5 & 64.3 & 57.2 & 39.5 & 15.2 & 33.3 & 20.7 & 34.4 \\
\hline $\mathbf{E u}$ & 0.1 & 0.6 & 0.5 & 0.4 & 0.2 & 0.5 & 1.2 & 0.5 \\
\hline Gd & 7.8 & 49.1 & 43.6 & 31.9 & 9.6 & 28.4 & 15.4 & 26.5 \\
\hline $\mathbf{T b}$ & 3.2 & 17 & 14.8 & 11.4 & 3.6 & 12 & 4.7 & 9.5 \\
\hline Dy & 29.2 & 129.5 & 117.1 & 94.9 & 30.8 & 112.8 & 41.1 & 79.3 \\
\hline Ho & 7.3 & 25.6 & 25.6 & 20.5 & 7 & 26.6 & 9.6 & 17.5 \\
\hline Er & 33.5 & 106.8 & 98 & 83.4 & 33.4 & 128.5 & 45.3 & 75.6 \\
\hline $\mathbf{T m}$ & 7.1 & 19.7 & 20 & 16.8 & 7 & 30.4 & 11.2 & 16 \\
\hline $\mathbf{Y b}$ & 56.8 & 157.8 & 163.1 & 127.4 & 57.8 & 286.6 & 104.6 & 136.3 \\
\hline Lu & 8.1 & 21 & 22 & 17.4 & 8.3 & 39.9 & 15.5 & 18.9 \\
\hline $\mathbf{Y}$ & 161.2 & 678.1 & 668.4 & 519.7 & 113 & 434.3 & 231.3 & 400.9 \\
\hline REEs & 339 & 1363 & 1401 & 1182 & 351 & 2811 & 653 & 1157.1 \\
\hline REE+Y & 501 & 2041 & 2070 & 1701 & 464 & 3245 & 884 & 1558 \\
\hline HREE & 153 & 527 & 504 & 404 & 158 & 665 & 247 & 379.7 \\
\hline LREE & 186 & 837 & 897 & 778 & 194 & 2146 & 406 & 777.7 \\
\hline $\mathrm{H}+\mathrm{Y}$ & 314.2 & 1205.1 & 1172.4 & 923.7 & 271 & 1099.3 & 478.3 & 780.6 \\
\hline $\mathrm{L} / \mathrm{H}+\mathrm{Y}$ & 0.59 & 0.69 & 0.77 & 0.84 & 0.72 & 1.95 & 0.85 & 1 \\
\hline $\mathrm{Ce}^{*}$ & 1.4 & 2.2 & 2.4 & 3.5 & 1.5 & 25.8 & 1.3 & 5.4 \\
\hline Eu* & 0.03 & 0.03 & 0.03 & 0.03 & 0.05 & 0.05 & 0.21 & 0.06 \\
\hline
\end{tabular}

Allanite, monazite, apatite and columbite are prevailing in protomylonites and ultramylonite rocks. The occurrence of the different mineral varieties in the cataclastics is largely due to the variation in the mineralogical composition of the sedimentary protolithes and the effects of alteration and supergene processes. Some of these minerals are inherited from the granitic rocks such as zircon, others from ophiolitic metagabbro (gold and silver) and some are introduced to the rocks by hydrothermal activity such as fluorite and others have been formed by supergene enrichment such as uranium minerals 


\section{GEOCHEMISTRY}

5-a. Alteration Features:However, the intensity of iron oxide concentrations in the studied rocks affected the field of hydrothermal alteration types according to the ternary diagram of ${ }^{21}$ where most samples show porpylitic and sericite field (Fig. 8). This propylitic alteration is manifested in the cataclastic rocks by the replacement of amphibole and pyroxene by epidote, carbonates. The losing or gaining of oxides of those hydrothermally cataclastic rocks can be shown on the triangular diagram $\left(\mathrm{Na}_{2} \mathrm{O}+\mathrm{CaO}\right) \mathrm{Al}_{2} \mathrm{O}_{3}-\mathrm{K}_{2} \mathrm{O}$ (Fig.9) after ${ }^{22,23}$. This diagram shows the weathering trend of the hydrothermally cataclastic rocks, where most samples are parallel along the $\left(\mathrm{Na}_{2} \mathrm{O}+\mathrm{CaO}\right) \mathrm{Al}_{2} \mathrm{O}_{3}$ side of the diagram (Fig.9). They reveal a loss of most of the $\mathrm{K}_{2} \mathrm{O}$ toward the $\mathrm{Al}_{2} \mathrm{O}_{3}$ apex, due to the relative alteration of feldspars to clay minerals.

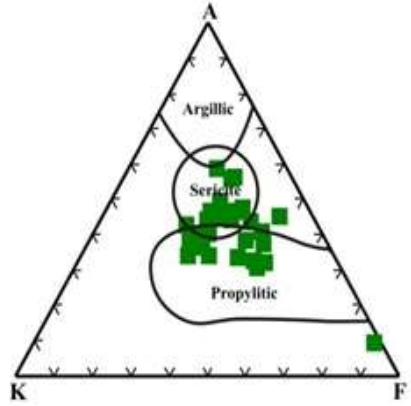

Fig. (8): $A K F$ ternary after $[21] \mathrm{A}=\mathrm{Al}_{2} \mathrm{O}_{3}-\left(\mathrm{Na}_{2} \mathrm{O}+\right.$ $\left.\mathrm{K}_{2} \mathrm{O}\right), \mathrm{K}=\mathrm{K}_{2} \mathrm{O}$ and $\mathrm{F}=\mathrm{FeO}+\mathrm{MnO}+\mathrm{MgO}$.

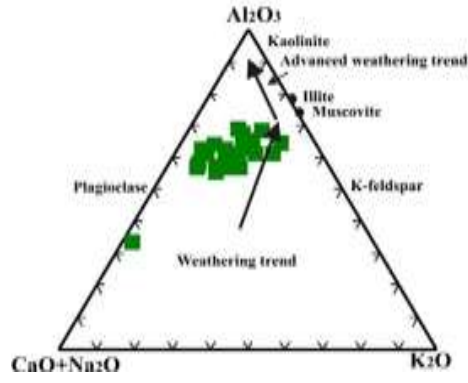

Fig. (9): $\mathrm{Al}_{2} \mathrm{O}_{3}-(\mathrm{CaO}+\mathrm{Na} 2 \mathrm{O})-\left(\mathrm{K}_{2} \mathrm{O}\right)$ ternary diagram for cataclastic rocks, after [22,23]

The Na-K variations diagram after ${ }^{24}$ shows five trends; Na-metasomatism, Kmetasomatism, silicification, de-silicification and argillation (Fig.10). Most of cataclastic samples lie in Nametasomatism and argillation trends. Alteration factors for cataclastic rocks $\left(\mathrm{Na}_{2} \mathrm{O}+\mathrm{CaO}_{2}(\mathrm{wt} \%)\right.$ against $\mathrm{MgO}+\mathrm{Fe}_{2} \mathrm{O}_{3}(\mathrm{wt} \%)$ diagram (Fig.11) showing plagioclase distraction due to sericitization.

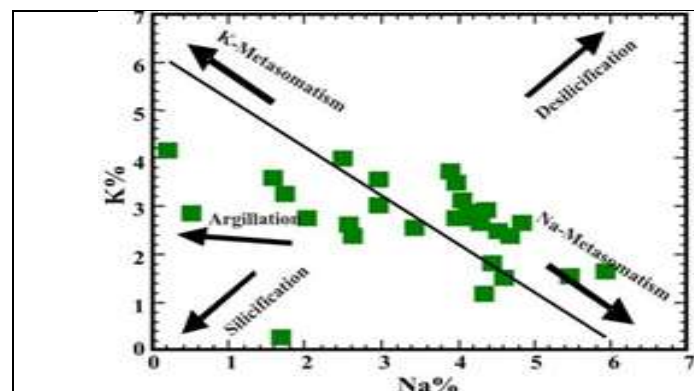

Fig. (10): $\mathrm{Na} \%$ - K\% variation diagram for cataclastic rocks.

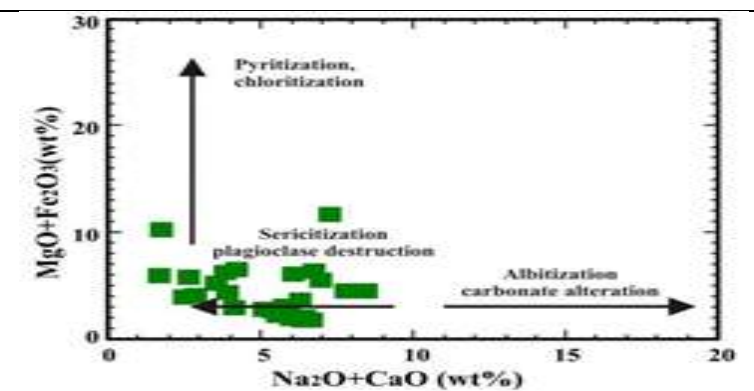

Fig. (11): Alteration factors for cataclastic rocks.

5-b.Trace Elements :The mylonites and lamprophyre dikes, are extremely rich in base metals $(\mathrm{Pb}$, $\mathrm{Zn}, \mathrm{Cu}$ and $\mathrm{As}$ ), precious metals ( $\mathrm{Au}$ and $\mathrm{Ag}$ ) and HFSE (e.g., U, Nb, HREE and $\mathrm{Y}$ ) found in the accessory minerals such as uranium minerals, columbite-(Fe), xenotime $(\mathrm{Y})$, allanite, zircon and fluorite. The cataclastic rocks are subjected to propylitic, sericitic, Na-metasomatism, ferrugination and argillation alterations, whereas lamprophyre dikes were underwent ferrugination, fluoritization, kaolinitization, sericitization, and calcification ${ }^{18}$.

The incompatible element ratios are usually utilized to characterize crustal contamination. The average $\mathrm{Nb} / \mathrm{U}$ ratio for upper crust and lower crust are 9 and 21, respectively. MORB and OIB show nearly constant $\mathrm{Nb} / \mathrm{U}$ ratio $(47+10)$, whereas the $\mathrm{Nb} / \mathrm{U}$ ratios for the rocks contaminated by crustal materials range ${ }^{25}$ from 9 to 40 . The average $\mathrm{Nb} / \mathrm{U}$ ratio of Abu Rusheid mylonite (1.2) and proto- to ultramylonite sample (2.4) is lower than the average for upper crust and lower crust (9 and21). Whereas, the average 
$\mathrm{Nb} / \mathrm{U}$ ratio of Abu Rusheid lamprophyres is 0.17 , suggesting that crust contamination during emplacement is not obvious.

Uranium contents in mylonite range from 88-4000 ppm with average 1342ppm, while Th ranges from 74-4000 ppm with average $1002 \mathrm{ppm}$ and U/Th ratio equal to 1.3 (gain) (Table 2). Uranium contents in protomylonite and ultramylonite range from 47-603 ppm with average $224 \mathrm{ppm}$, while Th ranges from 153-1745ppm with average $938 \mathrm{ppm}$ and U/Th ratio less than 0.24 (loss) except samples EG.10 and EG.30 (Table 3).

$\mathrm{Nb} / \mathrm{Ta}$ ratio more or less well-matched in both mylonite (8.3) and protomylonite and ultramylonite (9.6).furthermore, $\mathrm{Zr} / \mathrm{Hf}$ and $\mathrm{Nb} / \mathrm{U}$ ratios are compatible in the mylonite in one hand (18.5-1.2) and protomylonite and ultramylonite in the other hand (22.6-2.4) respectively. It can be conceivable that, the source of the cataclastic rocks (mylonite, protomylonite and ultramylonite) is same or similar.

In mylonite samples the correlation between $\mathrm{U}$ and some trace and rare earth elements, suggests very strongly positive relation with $\mathrm{HREE}, \mathrm{Nb}$, Ta, moderately with $\mathrm{Th}$ and very weakly negative with $\mathrm{Li}$ and $\mathrm{Ga}$. On the other hand, Th has very weakly positive relation with $\mathrm{Li}, \mathrm{Nb}, \mathrm{Ta}$, and $\mathrm{Zr}$ and negatively weakly with $\mathrm{Ag}, \mathrm{Sn}$ and Ga. The REEs have very strong positive relation with Y, and moderately to weakly with U (Table 4).

Table 4 : Correlation matrix between some trace elements and REEs in mylonite samples

\begin{tabular}{|c|c|c|c|c|c|c|c|c|c|c|c|c|c|c|c|c|c|c|c|c|c|c|}
\hline & $\mathbf{L a}$ & $\mathrm{Ce}$ & $\mathbf{P r}$ & Nd & $\mathrm{Sm}$ & $\mathbf{E u}$ & Gd & $\mathbf{T b}$ & Dy & Ho & $\mathbf{E r}$ & $\mathbf{T m}$ & $\mathbf{Y b}$ & $\mathbf{L u}$ & $\mathbf{Y}$ & $\mathbf{U}$ & Th & $\mathbf{Z r}$ & $\mathbf{L i}$ & $\mathbf{T a}$ & $\mathbf{N b}$ & Ga \\
\hline $\mathbf{L a}$ & 1.00 & & & & & & & & & & & & & & & & & & & & & \\
\hline $\mathrm{Ce}$ & 0.91 & 1.00 & & & & & & & & & & & & & & & & & & & & \\
\hline Pr & 0.98 & 0.84 & 1.00 & & & & & & & & & & & & & & & & & & & \\
\hline $\mathrm{Nd}$ & 0.97 & 0.81 & 1.00 & 1.00 & & & & & & & & & & & & & & & & & & \\
\hline $\mathrm{Sm}$ & 0.97 & 0.82 & 0.99 & 0.99 & 1.00 & & & & & & & & & & & & & & & & & \\
\hline $\mathbf{E u}$ & 0.70 & 0.49 & 0.73 & \begin{tabular}{|l|}
0.78 \\
\end{tabular} & o.80 & 1.00 & & & & & & & & & & & & & & & & \\
\hline Gd & 0.94 & 0.80 & 0.95 & $\mid 0.96$ & 0.98 & $\mid 0.86$ & 1.00 & & & & & & & & & & & & & & & \\
\hline $\mathbf{T b}$ & 0.90 & 0.77 & 0.90 & 0.91 & 0.95 & \begin{tabular}{|l|}
0.87 \\
\end{tabular} & (0.99 & 1.00 & & & & & & & & & & & & & & \\
\hline Dy & 0.85 & 0.75 & 0.84 & 0.85 & 0.90 & 0.86 & $|0.97|$ & \begin{tabular}{|l|}
0.99 \\
\end{tabular} & 1.00 & & & & & & & & & & & & & \\
\hline Ho & 0.82 & 0.72 & 0.80 & 0.81 & 0.86 & 0.86 & 0.94 & \begin{tabular}{|l|}
0.98 \\
\end{tabular} & 1.00 & 1.00 & & & & & & & & & & & & \\
\hline $\mathbf{E r}$ & 0.78 & 0.70 & 0.75 & \begin{tabular}{|l|}
0.76 \\
\end{tabular} & 0.82 & (0.84 & 0.91 & $\mid 0.96$ & \begin{tabular}{|l|}
0.99 \\
\end{tabular} & 1.00 & 1.00 & & & & & & & & & & & \\
\hline $\mathbf{T m}$ & 0.77 & 0.69 & 0.74 & \begin{tabular}{|l|}
0.75 \\
\end{tabular} & 0.81 & o.84 & 0.90 & 0.95 & 0.98 & 0.99 & 1.00 & 1.00 & & & & & & & & & & \\
\hline $\mathbf{Y b}$ & 0.79 & 0.73 & 0.75 & $\mid 0.76$ & 0.82 & o.83 & 0.91 & 0.95 & 0.98 & 0.99 & 1.00 & 1.00 & 1.00 & & & & & & & & & \\
\hline $\mathbf{L u}$ & 0.78 & 0.72 & 0.74 & \begin{tabular}{|l|}
0.75 \\
\end{tabular} & 0.81 & o.83 & 0.90 & 0.95 & 0.98 & 0.99 & 1.00 & 1.00 & 1.00 & 1.00 & & & & & & & & \\
\hline $\mathbf{Y}$ & 0.80 & 0.61 & 0.82 & 0.84 & 0.85 & 0.85 & o.88 & \begin{tabular}{|l|}
0.89 \\
\end{tabular} & 0.86 & 0.85 & 0.82 & \begin{tabular}{|l|} 
\\
\end{tabular} & 0.82 & 0.82 & 1.00 & & & & & & & \\
\hline $\mathbf{U}$ & 0.43 & 0.43 & 0.42 & 0.41 & 0.44 & o.30 & 0.45 & 0.45 & 0.44 & 0.42 & 0.40 & \begin{tabular}{|l|}
0.39 \\
\end{tabular} & 0.41 & 0.41 & \begin{tabular}{|l|}
0.32 \\
\end{tabular} & 1.00 & & & & & & \\
\hline $\mathbf{T h}$ & 0.49 & 0.69 & 0.39 & 0.35 & 0.38 & o.05 & $|0.37|$ & 0.35 & 0.36 & 0.34 & | 0.34 & \begin{tabular}{|l|}
0.33 \\
\end{tabular} & o.38 & 0.37 & | 0.08 & 0.50 & 1.00 & & & & & \\
\hline $\mathbf{Z r}$ & 0.09 & 0.18 & 0.10 & | 0.08 & 0.12 & -0.11 & 0.09 & 0.10 & o.08 & 0.04 & | 0.02 & \begin{tabular}{|l|}
0.02 \\
\end{tabular} & 0.03 & O.01 & \begin{tabular}{|l|}
0.12 \\
\end{tabular} & 0.33 & $\mid 0.13$ & 1.00 & & & & \\
\hline $\mathbf{L i}$ & -0.05 & -0.10 & -0.07 & -0.08 & -0.08 & -0.08 & -0.07 & -0.05 & -0.05 & -0.03 & -0.02 & -0.01 & -0.01 & 0.01 & 0.04 & -0.18 & 0.13 & -0.22 & 1.00 & & & \\
\hline $\mathbf{T a}$ & 0.08 & 0.12 & 0.09 & 0.07 & (0.07 & -0.11 & 0.05 & 0.02 & 0.00 & -0.01 & -0.02 & -0.04 & -0.02 & -0.03 & -0.18 & 0.69 & 0.30 & 0.11 & -0.45 & 1.00 & & \\
\hline $\mathrm{Nb}$ & 0.14 & 0.16 & 0.17 & 0.15 & 0.14 & -0.11 & 0.09 & 0.05 & O.02 & 0.00 & $-0.03 \mid$ & -0.05 & -0.03 & -0.04 & -0.11 & 0.63 & $|0.22|$ & 0.22 & -0.45 & 0.88 & 1.00 & \\
\hline $\mathbf{G a}$ & -0.59 & -0.44 & -0.59 & -0.63 & -0.63 & \begin{tabular}{|l|}
-0.82 \\
\end{tabular} & -0.68 & -0.69 & $\mid-0.69$ & -0.70 & $\mid-0.70$ & $\mid-0.70$ & $|-0.70|$ & $\mid-0.70$ & -0.61 & -0.13 & $\mid-0.04$ & \begin{tabular}{|l|}
0.41 \\
\end{tabular} & 0.12 & $\mid 0.15$ & 0.11 & 1.00 \\
\hline
\end{tabular}

REEs in protomylonite and ultramylonite samples show very strong relation with $Y$, weakly negative with $\mathrm{Zr}, \mathrm{Li}$ and $\mathrm{Ga}$, very weakly positive with $\mathrm{Th}$ and $\mathrm{Nb}$. Uranium shows negative weakly relation 
with $\mathrm{Th}, \mathrm{Ga}$ and $\mathrm{Li}$, and positive weakly with $\mathrm{Nb}, \mathrm{Ta}$ and $\mathrm{Zr}$. Th shows negative relation with $\mathrm{Zr}, \mathrm{Li}$ and $\mathrm{Ga}$, and weakly positive relation with $\mathrm{Nb}$ and $\mathrm{Ta}$ (Table 5).

In lamprophyre dikes, $\mathrm{U}$ - ranges from 681-1550 ppm with average $800 \mathrm{ppm}$, while Th ranges from 1$39 \mathrm{ppm}$ with average $20 \mathrm{ppm}$ and U/Th ratio equal to 40 (Table 6).Y (2396-5054ppm), $\mathrm{Cu}$ (228- 3060 ppm), Pb ( 158-10679 ppm), As ( 415-2092ppm), Zn ( 6343-18298ppm), Au (0.7-2.3 g/t) and Ag (24$30 \mathrm{ppm})$ contents are more enrichments in lamprophyre and mylonite than protomylonite and ultramylonite ( Table 6 ).

Table 5: Correlation matrix between some trace elements and REEs in protomylonites and ultramylonitesamples

\begin{tabular}{|c|c|c|c|c|c|c|c|c|c|c|c|c|c|c|c|c|c|c|c|c|}
\hline & La & $\mathrm{Ce}$ & Pr & Nat & $S m$ & Eu & Gd & $\mathrm{Tb}$ & Dy & $\mathrm{He}_{\mathrm{o}}$ & Er & $\mathrm{Tm}$ & $\mathbf{Y b}$ & Iu & $\mathbf{Y}$ & U & Th & $\mathrm{Zr}$ & U & Ta \\
\hline La & 1.00 & & & & & & & & & & & & & & & & & & & \\
\hline $\mathrm{Ce}$ & -0.2 & 1.00 & & & & & & & & & & & & & & & & & & \\
\hline Pr & 0.87 & 0.08 & 1.00 & & & & & & & & & & & & & & & & & \\
\hline Nd & 0.90 & 0.03 & 0.99 & 1.00 & & & & & & & & & & & & & & & & \\
\hline Sm & 0.77 & 0.25 & 0.98 & 0.96 & 1.00 & & & & & & & & & & & & & & & \\
\hline Eu & 0.55 & 0.05 & 0.23 & 0.34 & 0.19 & 1.00 & & & & & & & & & & & & & & \\
\hline Gd & 0.74 & 0.33 & 0.96 & 0.94 & 1.00 & 0.19 & 1.00 & & & & & & & & & & & & & \\
\hline $\mathbf{T b}$ & 0.63 & 0.46 & 0.90 & 0.87 & 0.97 & 0.12 & 0.99 & 1.00 & & & & & & & & & & & & \\
\hline Dy & 0.55 & 0.59 & 6.83 & 0.80 & 0.93 & 0.12 & 0.95 & 0.99 & 1.00 & & & & & & & & & & & \\
\hline Ho & 0.48 & 0.68 & 0.77 & 0.72 & 0.87 & 0.11 & 0.91 & 0.96 & 0.99 & 1.00 & & & & & & & & & & \\
\hline Er & 0.33 & 0.81 & 0.63 & 0.59 & 0.77 & 0.13 & 0.82 & 0.89 & 0.95 & 0.98 & 1.00 & & & & & & & & & \\
\hline Tm & 0.19 & 0.91 & 0.47 & 0.43 & 0.62 & 0,18 & 0.68 & 0.77 & 0.86 & 0.91 & 0.97 & 1.00 & & & & & & & & \\
\hline $\mathbf{Y b}$ & 0.09 & 0.95 & 0.34 & 0.31 & 0.50 & 0.21 & 0.56 & 0.66 & 0.77 & 0.84 & 0.93 & 0.99 & 1.00 & & & & & & & \\
\hline Lu & 0.07 & 0.96 & 0.36 & 0.27 & 0.46 & 0.24 & 0.52 & 0.63 & 0.73 & 0.81 & 0.90 & 0.98 & 1.00 & 1.00 & & & & & & \\
\hline $\mathbf{Y}$ & 0.74 & 0.35 & 0.94 & 0.91 & 0.98 & 0.16 & 0.99 & 0.98 & 0.96 & 0.92 & 0.83 & 0.69 & 0.58 & 0.53 & 1.00 & & & & & \\
\hline U & 0.48 & -0.05 & 0.73 & 0.73 & 0.77 & -0.09 & 0.73 & 0.70 & 0.61 & 0.51 & 0.43 & 0.24 & 0.14 & 0.10 & 0.65 & 1.00 & & & & \\
\hline Th & 0.34 & 0.12 & 0.23 & 0.15 & 0.14 & 0.01 & 0.18 & 0,17 & 0.20 & 0.26 & 0.18 & 0.20 & 0.17 & 0.16 & 0.31 & -0.34 & 1.00 & & & \\
\hline$Z r$ & -0.41 & -0.35 & -0.23 & -0.21 & -0.20 & -0.46 & -0.26 & -0.26 & -0.32 & -0.38 & -0.36 & -0.43 & -0.41 & -0.42 & -0.37 & 0.41 & -0.79 & 1.00 & & \\
\hline LI & -0.66 & 0.33 & -0.75 & -0.74 & -0.65 & -0.02 & -0.60 & -0.51 & $-0,41$ & -0.33 & -0.16 & 0.00 & 0.13 & 0.17 & -0.58 & -0.49 & -0.09 & -0.03 & 1.00 & \\
\hline $\mathrm{Ta}$ & 0.41 & 0.08 & 0.60 & 0.54 & 0.56 & -0.16 & 0.52 & 0.50 & 0.46 & 0.46 & 0.35 & 0.28 & 0.23 & 0.20 & 0.51 & 0.47 & 0.28 & 0.11 & -0.56 & 1.00 \\
\hline $\mathrm{Nb}$ & 0.41 & 0.05 & 0.55 & 0.49 & 0.50 & -0.09 & 0.46 & 0,43 & 0.39 & 0.39 & 0.29 & 0.24 & 0.20 & 0.18 & 0.45 & 0.40 & 0.31 & 0.08 & -0.52 & 0.99 \\
\hline Ga: & -0.48 & 0.23 & -0.49 & -0.48 & -0.42 & 0.01 & -0.42 & -0.37 & -0.32 & -0.26 & -0.13 & 0.00 & 0.13 & 0.16 & -0.48 & -0.11 & -0.31 & 0.40 & 0.66 & 0.08 \\
\hline
\end{tabular}

Table 6: Average of trace elements and REEs (ppm) in protomylonite and ultramylonite $(\mathrm{P} \& \mathrm{U})$, mylonite (M) and lamprophyres (Lamp.), Wadi Abu Rusheid area.

\begin{tabular}{|cccc|}
\hline Elements & P\&U & M & Lamp. \\
\hline $\mathbf{C u}$ & $\mathbf{3 4 3}$ & $\mathbf{5 5 8}$ & $\mathbf{1 1 0 6}$ \\
\hline $\mathbf{P b}$ & $\mathbf{1 5 3 6}$ & $\mathbf{4 6 5 7}$ & $\mathbf{4 5 2 6}$ \\
$\mathbf{Z n}$ & $\mathbf{1 5 8 0}$ & $\mathbf{2 8 3 6}$ & $\mathbf{1 1 2 9 2}$ \\
\hline $\mathbf{A g}$ & $\mathbf{4}$ & $\mathbf{3 0}$ & $\mathbf{2 4}$ \\
$\mathbf{U}$ & $\mathbf{2 2 4}$ & $\mathbf{1 3 4 2}$ & $\mathbf{8 0 0}$ \\
\hline $\mathbf{T h}$ & $\mathbf{9 3 8}$ & $\mathbf{1 0 0 2}$ & $\mathbf{2 0}$ \\
\hline $\mathrm{Bi}$ & $\mathbf{3 1}$ & $\mathbf{8 7}$ & n.d. \\
\hline $\mathrm{Zr}$ & $\mathbf{3 1 9}$ & $\mathbf{5 5 7}$ & $\mathbf{3 2 5}$ \\
\hline $\mathrm{Sn}$ & $\mathbf{6 9}$ & $\mathbf{1 4 9}$ & $\mathbf{5}$ \\
\hline $\mathrm{Be}$ & $\mathbf{1 4 8}$ & $\mathbf{3}$ & $\mathbf{1}$ \\
\hline $\mathbf{Y}$ & $\mathbf{4 0 1}$ & $\mathbf{6 6 3}$ & $\mathbf{3 7 8 8}$ \\
\hline $\mathbf{L i}$ & $\mathbf{9 7 8}$ & $\mathbf{7 6 7}$ & $\mathbf{5 4 0}$ \\
\hline $\mathbf{R b}$ & $\mathbf{7 0 2}$ & $\mathbf{8 2 1}$ & $\mathbf{5 5 0}$ \\
\hline
\end{tabular}




\begin{tabular}{cccc}
\hline Ta & 43 & 141 & 4 \\
Nb & 395 & 774 & 134 \\
\hline Ga & 73 & 65 & n.d. \\
Au & 0.0 & 2.3 & 0.70 \\
\hline LREEs & 777.7 & 531 & 986 \\
\hline HREEs & 379.7 & 1207 & $\mathbf{3 2 5 0}$ \\
\hline L/H & $\mathbf{2 . 0 5}$ & $\mathbf{0 . 4 4}$ & $\mathbf{0 . 3 0}$ \\
\hline U/Th & $\mathbf{0 . 2 4}$ & 1.34 & $\mathbf{4 0 . 0}$ \\
\hline
\end{tabular}

5-c. Rare -Earth Elements : The REEs in the Abu Rusheid area are subdivided into: a) HREEs- bearing mylonite and lamprophyre and b) LREEs- bearing protomylonite and ultramylonite (Tables 2, 3\&6).

\section{CATACLASTIC ROCKS}

a. HREEs- bearing mylonite: The mylonite show upward-sloping Chondrite- normalized REE pattern (Fig.12) where average HREEs (1207 ppm) is higher than LREE (530 ppm) and LREE / HREE $=0.44$. The mylonite average samples are characterized by reverse fractionated REE patterns $[(\mathrm{La} / \mathrm{Yb}) \mathrm{N}=$ $0.13]$ and pronounced negative Eu anomalies $\left(\mathrm{Eu} / \mathrm{Eu}^{*}=0.08\right)$ with HREE enrichment $[(\mathrm{Gd} / \mathrm{Lu}) \mathrm{N}=$ 0.14] ( Fig.12). Eu anomaly could be related to REE mobility ${ }^{26}$ or due to Eu leaching by the volatile phase rich in fluorine, $\mathrm{H}_{2} \mathrm{O}$ and low temperature $(6500 \mathrm{C})[27,28]$ or attributed to sericitization ${ }^{29,30}$ The presence of positive Ce anomaly in mylonite samples suggests oxidizing conditions under which the REEs were precipitated ${ }^{31}$. The HREE enrichment in mylonite is attributed to some heavy minerals (e.g. xenotime, fergusonite, zircon and fluorite).

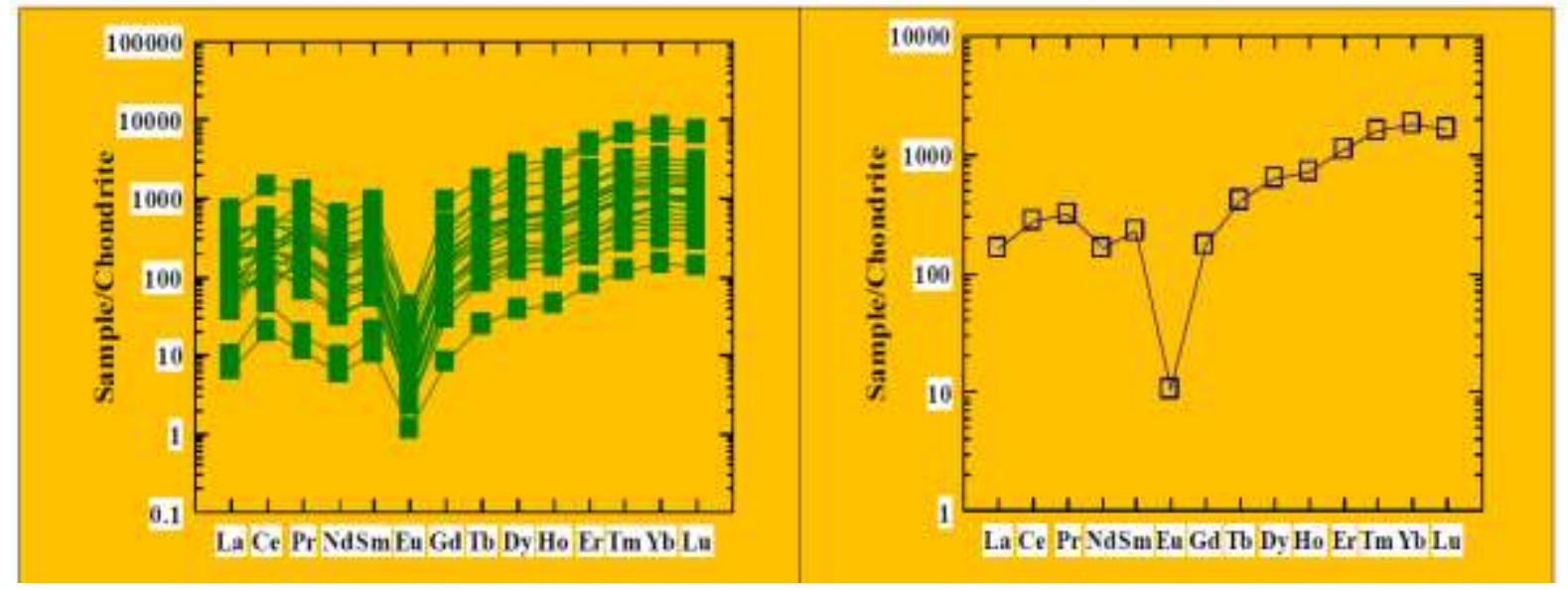

Fig. (12): Chondrite-normalized REE patterns of mylonite (A) and their average (B), the Chondritic values after ${ }^{26}$

b. LREEs - bearing protomylonite and ultramylonite; The protomylonite and ultramylonite show upward-sloping chondrite- normalized REE pattern (Fig.13) where average LREEs (777 ppm)) is higher than HREE (379ppm) and with (LREE / HREE = 2.05). The LREE enrichment in protomylonite and ultramylonite is attributed to some heavy minerals (e.g. allanite-(Ce), apatite and monazite-(Ce). The average REE in protomylonite and ultramylonite samples are characterized by reverse fractionated REE patterns $[(\mathrm{La} / \mathrm{Yb}) \mathrm{N}=0.13]$ and pronounced negative Eu anomalies $\left(\mathrm{Eu} / \mathrm{Eu}{ }^{*}=0.06\right)(\mathbf{F i g} .14)$ and positive $\mathrm{Ce}$ anomaly $\left(\mathrm{Ce} / \mathrm{Ce}^{*}\right)$ which is attributed to occurrence of monazite- $(\mathrm{Ce})$ in oxidizing conditions. 


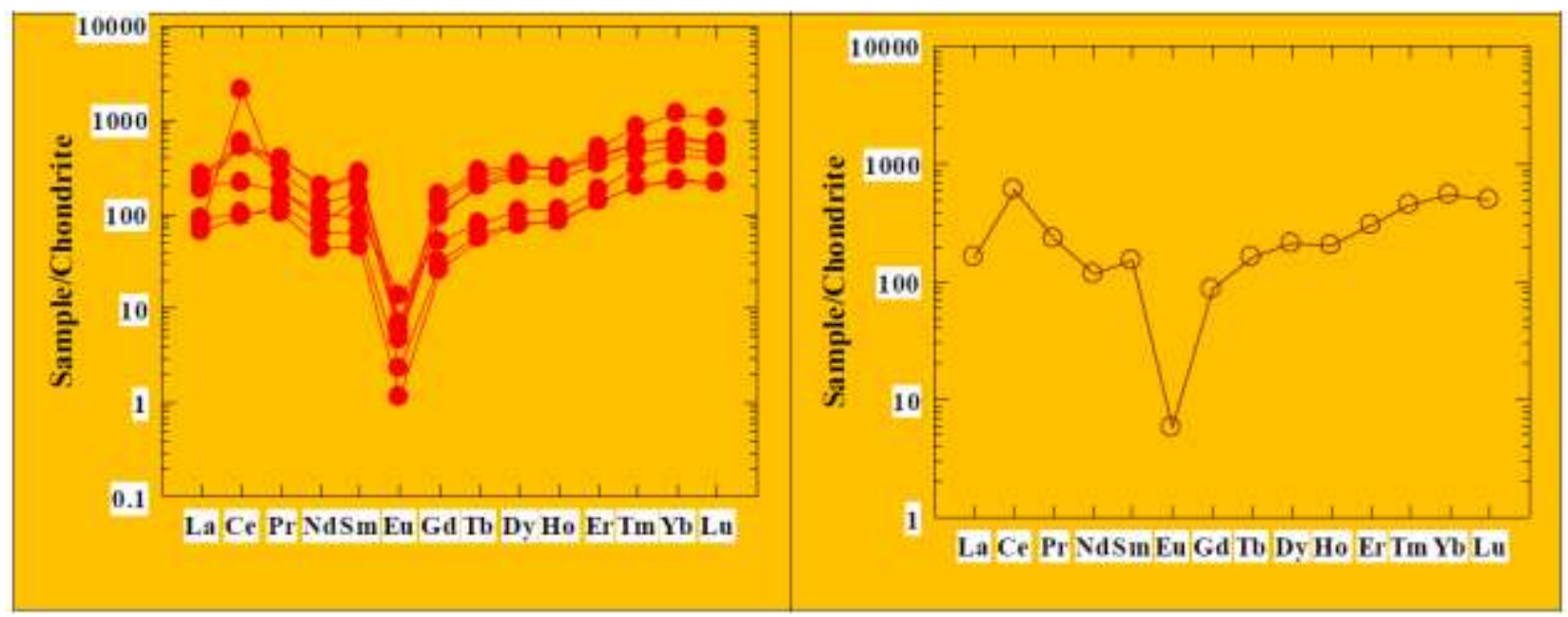

Fig. (13): Chondrite-normalized REE patterns of ultramylonite and protomylonite (A) and their average (B), the Chondritic values after ${ }^{26}$.

2- HREEs- bearing Lamprophyre dikes : The Abu Rusheid lamprophyre dykes have average HREE (3250 ppm) higher than LREE (986 ppm) with (LREE/HREE =0.30), (Tables 7\&8). The HREE enrichment in lamprophyres is attributed to some heavy minerals (e.g. xenotime, fergusonite, zircon and fluorite.The average REE in lamprophyre samples are characterized by reverse fractionated REE patterns $[(\mathrm{La} / \mathrm{Yb}) \mathrm{N}=0.13]$ and pronounced negative Eu anomalies $\left(\mathrm{Eu} / \mathrm{Eu}^{*}=0.08\right)$. They displays the $\mathrm{W}$-type tetrad effect of both $\mathrm{T} 3$ and $\mathrm{T} 4{ }^{28}$ due to the alteration (thermal effect from saturated fluid solution) (Fig.14), [18]. It is concluded that presence of negative $\mathrm{Ce}$ anomaly suggests mobilization of REE under reducing conditions. Lamprophyre dykes have nonchondritic ratios of isovalent elements; $\mathrm{Zr} / \mathrm{Hf}$ (21-35), Y/Ho (23-9), Nb/Ta (930) due to hydrothermal alterations (alkali metasomatism).

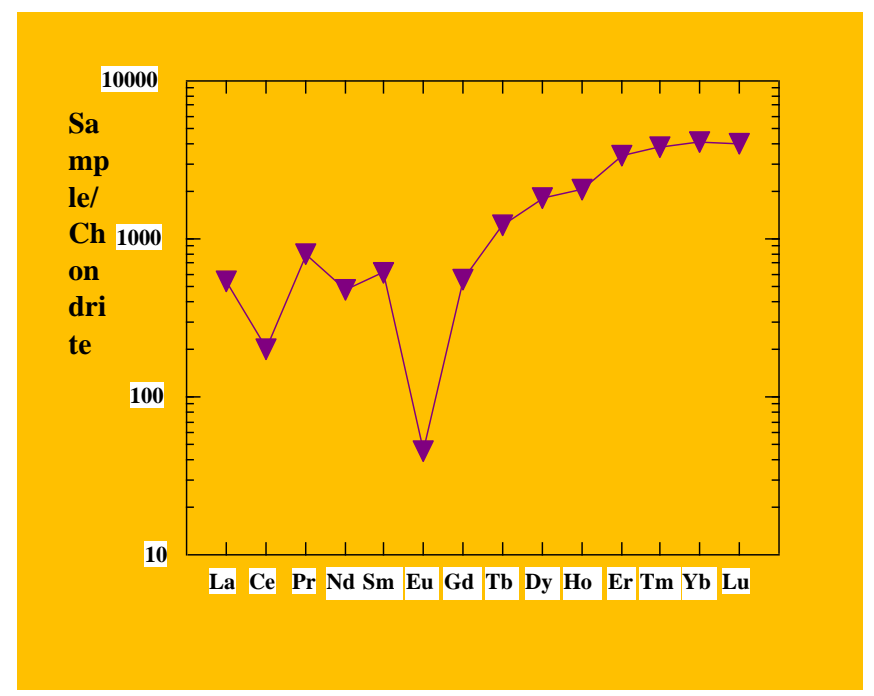

Fig. (14): Chondrite-normalized REE patterns for average lamprophyre dikes samples after ${ }^{18}$.The chondritic values after ${ }^{26}$ 
Table 7: Major oxides (wt $\%)$ and trace elements (ppm) of lamprophyre dikes at Abu Rusheid area, $\operatorname{after}^{15,18}$

\begin{tabular}{|c|c|c|}
\hline & L1 $\quad(n=6)$ & L2 $\quad(n=6)$ \\
\hline $\mathrm{SiO} 2$ & $42.7-43.8$ & $42.64-54.07$ \\
\hline $\mathrm{TiO}_{2}$ & $2.3-3.8$ & $3.80-4.11$ \\
\hline $\mathrm{A} 12 \mathrm{O} 3$ & $17.0-20.01$ & $14.09-8.99$ \\
\hline $\mathrm{FeO}$ & $16.80-20.0$ & $11.89-19.51$ \\
\hline $\mathrm{MnO}$ & $0.50-1.50$ & $0.12-0.44$ \\
\hline $\mathrm{MgO}$ & $0.01-0.06$ & $1.63-3.19$ \\
\hline $\mathrm{CaO}$ & $0.70-2.10$ & $0.61-11.16$ \\
\hline $\mathrm{Na} 2 \mathrm{O}$ & $0.47-050$ & $0.33-2.66$ \\
\hline $\mathrm{K} 2 \mathrm{O}$ & $2.14-2.88$ & $1.31-3.89$ \\
\hline $\mathrm{P} 2 \mathrm{O} 5$ & $0.25-2.30$ & $0.40-0.80$ \\
\hline L.O.I. & $8.03-9.70$ & $2.90-6.93$ \\
\hline $\mathrm{Ba}$ & $167-236$ & $364-545$ \\
\hline $\mathrm{Nb}$ & $66-127$ & $131-214$ \\
\hline $\mathrm{Rb}$ & $466-530$ & $459-627$ \\
\hline Sn & $4-6$ & $2-5$ \\
\hline $\mathrm{Sr}$ & $43-75$ & $1-50$ \\
\hline $\mathrm{Th}$ & 8- 39 & $1-8$ \\
\hline $\mathrm{U}$ & $681-840$ & $749-1550$ \\
\hline $\mathrm{V}$ & $240-324$ & $440-450$ \\
\hline $\mathrm{W}$ & $146-802$ & $440-450$ \\
\hline $\mathrm{Zr}$ & $264-378$ & $310-348$ \\
\hline $\mathrm{Y}$ & $2900-5054$ & $2396-4802$ \\
\hline Mo & $1-4$ & $1-2$ \\
\hline $\mathrm{Cu}$ & $228-351$ & $787-3060$ \\
\hline $\mathrm{Pb}$ & $158-545$ & $6723-10679$ \\
\hline $\mathrm{Zn}$ & $6343-9049$ & $11478-18298$ \\
\hline $\mathrm{Ni}$ & $10-15$ & $108-208$ \\
\hline As & $415-642$ & $1193-2092$ \\
\hline $\mathrm{Ag}$ & $1-12$ & $17-67$ \\
\hline $\mathrm{Ta}$ & $4-5$ & $2-6$ \\
\hline $\mathrm{Hf}$ & $6-10$ & $6-12$ \\
\hline
\end{tabular}

Table 8: Average result of REEs (ppm) in N$\mathrm{S}$ lamprophyre dikes (12 samples), Abu Rusheid area after ${ }^{18}$

\begin{tabular}{|c|c|}
\hline La & 199 \\
\hline $\mathrm{Ce}$ & 192 \\
\hline $\mathrm{Pr}$ & 110 \\
\hline Nd & 340 \\
\hline $\mathrm{Sm}$ & 141 \\
\hline Eu & 4 \\
\hline Gd & 167 \\
\hline $\mathrm{Tb}$ & 71 \\
\hline Dy & 689 \\
\hline Ho & 174 \\
\hline Er & 843 \\
\hline $\mathrm{Tm}$ & 137 \\
\hline $\mathrm{Yb}$ & 1018 \\
\hline $\mathrm{Lu}$ & 151 \\
\hline $\mathbf{Y}$ & 3770 \\
\hline ¿REE & 4236 \\
\hline$\Sigma \mathrm{REE}+\mathrm{Y}$ & 8006 \\
\hline इLREE & 986 \\
\hline$\Sigma$ HREE+Y & 7020 \\
\hline $\begin{array}{l}\Sigma \text { LREE/ } / \text { HREE } \\
+\mathbf{Y}\end{array}$ & 0.14 \\
\hline$(\mathrm{La} / \mathrm{Yb}) \mathrm{N}$ & 0.13 \\
\hline$(\mathrm{La} / \mathrm{Sm}) \mathrm{N}$ & 0.89 \\
\hline$(\mathrm{Gd} / \mathrm{Lu}) \mathrm{N}$ & 0.14 \\
\hline $\mathrm{Eu} / \mathbf{E u}^{*}$ & 0.08 \\
\hline $\mathrm{Ce} / \mathrm{Ce}^{*}$ & 0.4 \\
\hline
\end{tabular}

\section{CONCLUSION \& DISCUSSION}

1. Abu Rusheid area is regarding as closed basin (Fig. 1b) elongated in NW-SE (12km) and thinning in NE-SW (4km). Hard and compact ophiolitic metagabbro forms the high peripheral parts of the basin and thrusted over the ophiolitic mélange. The banded cataclastic rocks are subdivided from base to top into; protomylonites, mylonites, ultramylonites and quartzite. They were deposited in the central part of basin, intercalated with each other's or with biotite schist. They are subjected to regional metamorphism (sillmanite- kaynite - garnet facies). Mafic ultramafic ophiolitic rock fragments are enclosed within the cataclastic rocks. During late stage of anatexis, silica is predominant phase than alumina due its higher mobility, and silicified ultramylonite (quartzite) was formed at the top of cataclastic rocks without banding or 
gneissosity. These rocks were intruded by Post-to late orogenic biotite granites and biotite muscovite granites with sharp contacts. Post magmatic activities were representing by lamprophyre dikes, pegmatite segregation and quartz veins dissected all the previous rocks in variable trends.

2. The petrographical and mineralogical studies reflected that, the cataclastic rocks are subjected to many types of hydrothermal alterations including, propylitic, sericitic,, Na-metasomatism, ferrugination and argillation. Whereas lamprophyre dikes were underwent multistage hydrothermal processes such as ferrugination, fluoritization, kaolinitization, sericitization, and calcification.

3. The mylonites are characterized by well-developed $\mathrm{Li}, \mathrm{U}, \mathrm{Th}, \mathrm{Au}, \mathrm{As}, \mathrm{Pb}, \mathrm{Zn}, \mathrm{Sn}$ and $\mathrm{Cu}$ enrichments respectively. Li-rich magma probably formed by partial melting of Li-bearing metasediments at temperatures $75^{\circ} \mathrm{C}$ or more ${ }^{32}$ near the sillimanite isograd in metamorphic rocks. The common minerals that have been recognized in mylonite are represented by zinnwaldite, U- minerals (soddyite, uranophane, kasolite, torbernite and meta- zeunerite), Thminerals (thorite and uranothorite), and gold, cassiterite, scheelite, and $\mathrm{Nb}-\mathrm{Ta}$ minerals ${ }^{19}$.Uranophane, kasolite and torbernite are recorded in protomylonites and ultramylonites, whereas, soddyite, uranophane, kasolite and torbernite are common in lamprophyres. Thorium minerals (thorite and uranothorite) are clear in cataclastic rocks only. The average $\mathrm{U} / \mathrm{Th}$ ratio in mylonite and lamprophyre dikes (1.32 and 40.0) is exceeding than average of crust (0.33), illustrate uranium gain, whereas in protomylonite and ultramylonite samples, their U/ Th ratio (0.24) is less than the average of crust, denote uranium loss. Also, testing of uranium equilibrium by ${ }^{19}$ recorded major chemical $U$ addition $\left(U_{\text {chem }} / \mathrm{eU}=3\right)$ in the mylonites and lamprophyre samples as indication for young surficial uranyl mineralization.

4. The mylonites and lamprophyre dikes, are extremely rich in base metals ( $\mathrm{Pb}, \mathrm{Zn}, \mathrm{Cu}$ and $\mathrm{As}$ ), precious metals ( $\mathrm{Au}$ and $\mathrm{Ag}$ ) and in HFSE (e.g.,U, Nb, HREE and $\mathrm{Y}$ ) found in the accessory minerals such as secondary uranium minerals, columbite-(Fe), fluorite, xenotime (Y), allanite, zircon, fluorite and monazite-(Ce).

5. The descending (infiltrational) mineralization-bearing hydrothermal solutions are mainly derived from meteoric water, migrating under gravity from high relief peripheral hot uraniferous muscovite-biotite granite to low central part of the basin (cataclastic rocks) and redeposited along banding planes and fractures in mylonite .

6. After the emplacement of lamprophyre dikes (mantled-derived with high temperature and volatiles, as well as, $\mathrm{CO}_{2}{ }^{18}$ ), the ascending (exfiltrational) hydrothermal solutions are dominantly derived from groundwater, and are mainly derived by high gas pressures penetrating into the basin, along banding planes and fractures in the host rocks with low temperatures and containing $\mathrm{F} 1-$ and $\mathrm{CO}_{3} 2-, \mathrm{PO}_{4} 3^{-}$and $\mathrm{H}_{2} \mathrm{O}$ caused redistribution; transportation and redeposition of the base metals $(\mathrm{Pb}, \mathrm{Zn}, \mathrm{Cu}$ and $\mathrm{As})$, precious metals $(\mathrm{Au}$ and $\mathrm{Ag}$ ) and in HFSE (e.g. Nb, HREE and Y), along the channel ways (banding of the cataclastic rocks and fractures) to the shear zones (N-S) and precipitated in boxworks and adsorbed on clay minerals.

7. The lamprophyre dikes and mylonites are characterized by ferrugination (high total iron). The latter indicates the presence of alkali hydrothermal solution, may precipitate $\mathrm{Fe}^{+3}$ and $\mathrm{U}^{+6}$ within micro-fractures in the form of iron-oxy-hydroxides rich in uranium. The occurrences of U- 
minerals in the pores (fractures and veins) indicate that, these minerals were deposited from solutions descending or ascending that permeated the micro-porous.

8. Desulfidization process took place in the cataclastic rocks and lamprophyre dikes, where sulfide minerals such as pyrite, chalcopyrite and sphalerite are easily oxidized by ground water in the presence of oxygen to produce either ferric oxide or its hydrate analog, leaving boxworks. The release of $\mathrm{Ca}$ and $\mathrm{F}$ during illitization of plagioclases and biotite may combine together to form calcium fluoride $\left(\mathrm{Ca} \mathrm{F}_{2}\right)$. This kind of alteration by acid solution is responsible for leaching mineralization from the banded mylonites, transported and adsorbed on the margins of N-S lamprophyre dikes (chemical trap for mineralization) ${ }^{18}$

9. The presence of precious metals ( $\mathrm{Ag}$ and $\mathrm{Au}$ ) is attributed to the Bi-chalcogenides which act as scavengers and hosts for $\mathrm{Au}$ and $\mathrm{Ag}^{33}$. The relative values of $\mathrm{Au}$ and $\mathrm{Ag}$ reflect their geological abundances. $\mathrm{Ag} / \mathrm{Au}$ ratios in epithermal deposits range from 1 to about 400 and average about 35 , not greatly different from the ratio of their crustal abundances. The average ratio of $\mathrm{Ag} / \mathrm{Au}$ in mylonite (13) is less than that in lamprophyre dikes ${ }^{34}$. The higher contents of As in mylonite samples $(1546 \mathrm{ppm})$ matching with Au contents $(2.3 \mathrm{~g} / \mathrm{ton})$. They may be derived from ophiolitic metagabbro. Gold transported in solution as $\mathrm{Au}-\mathrm{Cl}$ and $\mathrm{Au}-\mathrm{S}$ complexes by ascending hydrothermal waters (in the presence of fluorite) through channel ways (faults, fractures and bedding) and deposited at temperatures between $300^{\circ} \mathrm{C}$ and $400^{\circ} \mathrm{C}$ and pressures of 1 to $2 \mathrm{k}$-bars. The change of physicochemical conditions such as temperature, pressure, oxygen fugacity, and sulfur fugacity are effective mechanisms for gold precipitation as (epithermal deposits) $^{34}$. Epithermal deposits can transport quite a few metals, including $\mathrm{Hg}, \mathrm{Sb}$, As, $\mathrm{U}, \mathrm{V}, \mathrm{Ag}$ and $\mathrm{Au}$, and redeposit them.

10. A threefold classification of REY was used after ${ }^{35}$; light (LREY; La, Ce, Pr, Nd, and Sm), medium (MREY; Eu, Gd, Tb, Dy, and Y) and heavy (HREY; Ho, Er, Tm,Yb,and Lu). Moreover, three REEs enrichment types are identified: L-type (light-REY; $\left.(\mathrm{La} / \mathrm{Lu})_{\mathbf{N}}>1\right), \mathrm{M}-$ type ( medium-REY; (La/Lu)N< 1), and H-type (heavy-REY; (La/Lu) $\mathrm{N}<1$ ). Lamprophyre samples show MREY (4701 ppm) > HREY (2323ppm) > LREY (982 ppm). The same result was obtained from mylonite samples, where, MREY> (1197.6ppm)> HREY (893.8 ppm) > LREY (529ppm).The HREEs minerals are represented by xenotime, fergusonite, fluorite and zircon. In contrast, protomylonite and ultramylonite have enrichment in LRET (777ppm) > MREY (516.6ppm) > HREY (246.3 ppm) [(Gd/Lu) N= 0.14] (Tables 2, 3, 6 \& 8).

11. The depletion of REEs has been attributed to various processes including magmatic differentiation ${ }^{24}$, hydrothermal leaching ${ }^{36}$ and or a combination of both. The metasomatic process may also cause severe leaching of REE from the albitized rock (e.g.Na-metasomatism in mylonite). The REE depletion may be related to the transformation of accessory minerals such as monazite to apatite and thorite in some hybrid rocks ${ }^{37}$. The accessory minerals and their sequence of crystallization play a major role in controlling the geochemical behavior of $U$ and Th in silicate melts, ${ }^{38}$. The early crystallization of thorite and/ or monazite would lead to significant U-enrichment in residual fluids (case study: mylonite). On the other hand, the early crystallization of zircon and / or apatite would lead to Th- enrichment in the residual fluids (case study: protomylonites and ultramylonites). The crystallization of uranothorite does not have any fractionation effect on $\mathrm{U}$ and $\mathrm{Th}^{39}$.

12. The hematization process (a good trap for REEs) has caused the enrichment of the REEs in lamprophyre and mylonite samples. Precipitation of hematite probably decreased the $\mathrm{pH}$ of the solution and rising acidic fluids ${ }^{40}$. 


\section{REFERENCES}

1. E.Z.Basta, and M.Zaki, Geology and mineralization of Wadi Sikait area, South Eastern Desert. J. geol. U. A. R., 1961, 5(1), 1-38.

2. E.M.El-Shazly, and M.A.Hassan, Geology and radioactive mineralization at Wadi Sikait-Wadi El-Gemal area. South Eastern Desert, Egypt. J. Geol.1972, 16 (2), 201-233

3. M.A.Hassan, Geology and geochemistry of radioactive columbite-bearing psammitic gneiss of Wadi Abu Rusheid. South Eastern Desert, Egypt. Ann. Geol. Surv. Egypt. III,1973, 207-225.

4. A.H.Sabet, V.B.Tsogoev, V.P.Bordonosov, R.G.Shoblovsky, and M.Kossa, On the geologic structures, laws of localization and prospects of Abu Rusheid rare metals deposit. Ann. Geol. Surv. Egypt., VI.1976, 181-197

5. M.A.Hassan, M.M.Aly and A.S.Eid, Petrographical and geochemical studies on the radioactive psammitic gneiss of Wadi Abu Rusheid, Eastern Desert, Egypt. Ann. Geol. Surv. Egypt.1983, XIII, 143155.

6. M.A. El-Gemmizi, On The occurrence and genesis of mud zircon in the radioactive psammitic gneiss of Wadi Nugrus, Eastern Desert, Egypt. J. Univ. Kuwait,1984, 1, 285- 294.

7. H.M.Hegazy, Geology of Wadi El-Gemal area. Eastern Desert, Egypt. Ph. D. Thesis, Assiut Univ., Egypt,1984, 271 p.

8. M.E.Hilmy, R.M.El-Bayoumi, and A.S.Eid, Geology geochemistry, and mineralization of the Psammitic gneiss of Wadi Abu Rusheid, Eastern Desert, Egypt. J. Afr. Earth Sci., 1990,11, 197-205.

9. H.S.Ssaf, M.E.Ibrahim, A.A.Zalata, A.A.El-Metwally, and G.M. Saleh,Ployphase folding in Nugrus-Sikait area, South Eastern Desert, Egypt.The 4th International conf. On the Geology of the Arab world, Cairo Univ., Egypt.Abstract.1998, p. 131.

10. H. S.Assaf, M. E.Ibrahim, A. A.Zalata, A. A.El- Metwally, and G. M.Saleh, (2000): Polyphase folding in Nugrus-Sikait area south Eastern Desert, Egypt. JKAW: Earth Sci., 12, 1-16 p.

11. G.M.Saleh, The potentiality of uranium occurrences in Wadi Nugrus area, south Eastern Desert, Egypt. Ph. D. Thesis Mans. Univ., 1997, 171 (12):1-16p.

12. M. E.Ibrahim, G. M.Saleh, H. H.Abd El Naby, T.Amer, F. O.Mahmoud, A. A.Abu El Hassan, I. H.Ibrahim, M. A.Aly, M. A.Rashed, F. M.Khalel, and M. A.Mahmoud, Uranium and associated rare metals potentialities of Abu Rusheid brecciated shear zone I, south Eastern Desert, Egypt. (Internal report, Unpublished).2002,107 p.

13. M. E.Ibrahim, G. M.Saleh, I. H.Ibrahim, T.Amer, F. O.Mahmoud, A. A.Abu El Hassan, M. A.Aly, M. S.Azab, M. A.Rashed, F. M. Khalealand M. A.Mahmoud, Uranium and associated rare metals potentialities of Abu Rusheid brecciate shear zone II, south Eastern Desert, Egypt. (Internal report, Unpublished)2004.

14. M. A.Rashed, Geologic studies on a new occurrence of Nuclear Materials in Abu Rusheid Area, South Eastern Desert, Egypt., Ph.D. Thesis, faculty of science (Demiatta), Mansoura University,2005 174p.. 
15. M. E.Ibrahim, M. M.El Tokhi, G. M.Saleh and M. A.Rashed, Lamprophyre bearing-REEs, South Eastern Desert, Egypt. 7th Intern.Conf. on Geochemistry, Fac. Sci., Alex.Univ., Alex., Egypt,2006, 6-7 Sept.

16. M. E.Ibrahim, G. M.Saleh, M. A.Hassan, M. M. El-Tokhi, and M. A.Rashed,Geochemistry of lamprophyres bearing uranium mineralization, Abu Rusheid area, south Eastern Desert, Egypt. The 10th Inter. Min., Petrol., and Metall. Eng. Conf., Assuit Univ.,2007 41-55p.

17. M.E.Ibrahim, G.M.Saleh, N.A.Dawood, G.M.Aly, Ocellar lamprophyre dyke-bearing polymineralization at Wadi Nugrus, Eastern Desert of Egypt: mineralogy and geochemical implications. J Geol Min Res,2010, 2(4):74-86p.

18. M. E.Ibrahim, K.Watanabe, G. M.Saleh, and W. S.Ibrahim, Abu Rusheid lamprophyre dikes, South Eastern Desert, Egypt: as physicalchemical traps for REEs, Zn, Y, U, Cu, W, and Ag. Arab J Geosci.2015, DOI 10.1007/s12517-015-1882-8.

19. M.E.Ibrahim,M.S.Kamar, M.S. Saleh,A. El- Tohamy, and E.Korany,Gold and uranium mineralization in mylonite and mica schist, Abu Rusheid area (Internal Report, Unpublished)2018,.

20. G. M.Saleh, I. H.Ibrahim, F. O.Mahmoud, A. A.Abu El Hassan, M. A.Rashed, F. M.Khalel, and M. A.Mahmoud, and others, Uranium potentiality of Abu Rusheid area, South Eastern Desert, Egypt. (Internal report Unpublished,)2010

21. C.Meyer, and J.J. Hemley, Wall rock alteration in geochemistry of ore deposits, H. L. Barnes, ed., New York,1967, 166 - 235 p.

22. H.W.Nesbitt, and G.M.Young, Prediction of some weathering trends of plutonic and volcanic rocks based up on thermodynamic and kinetic consideration. Geochim.Cosmochim.Acta,1984, 48, 1523-1534 p.

23. H.W. Nesbitt,and G.M.Young, Formation and digenesis of weathering profiles. J. Geol., V. 1989, 97, 129-147 p.

24. M.Cuney, and M.Friedrich, Physicochemical and crystal -chemical controls on accessory mineral paragenesis in granitoids; Implications for uranium metallogenesis .Bull. Mineral.,1987,110-235-247p.

25. M.Gregoire, J.P.Lorand, S.Y.Oreilly, and J.Y.Cottin, A rmalcolitebearing Ti-rich metasomatic assemblages in harzburgitic xenoliths from the Kerguelen Island; implications from the oceanic mantle budget of high-filed strength elements [J]. Geochim. Et Cosmochim. Acta.2000, 64, 673-694p.

26. S.R.Taylor, S.M.McLennan, The continental crust: its composition and evolution. Blackwell Scientific Publication, Carlton, 1985,312 p.

27. W.V.Boynton,Geochemistry of the rare earth elements ;Meteoric studies In:Rare Earth Elements Geochemistry (Henderson,P.,Ed.)Elsevier Pub.Co.Amesterdam,1984,63-114p

28. Monecke, T., Kempe, U., Monecke, J., Sala, M., Wolf, D., (2002): Tetrad effect in rare earch element distribution patterns: a method of quantification with application to rock and mineral samples from granite-related rare metal deposits. Geochim.Cosmochim.Acta 66, 1185-1196p.

29. D.H.Alderton, J.A.Pearce, and P.J.Potts, Rare earth elements mobility during granite alteration: evidence from Southwest England. Earth Planet Sci.1980, 49:149-165p. 
30. M.Bau, Controls on the fractionation of isovalent trace elements in magmatic and aqueous systems: evidence from $\mathrm{Y} / \mathrm{Ho}, \mathrm{Zr} / \mathrm{Hf}$, and lanthanide tetrad effect. Contrib. Mineral. Petrol.1996, 123, 323-333p.

31. P.Henderson, Rare earth elements geochemistry. Amestrdam, Elsevier,1994, 510p.

32. M. J.Holdaway, Stability of andalusite and the aluminum silicate phase diagramm. Am. J. Sci.,1971, 271, 29-131p.

33. C.Ciobanu,N.J.I.Cook,,A.Pring,J.Brugger , L.Danushevsky,M.Shimizu,Invisible gold in bismut chalcogenidesGeochim.Cosmochim.,Acta,2009, 73,1970-1999p.

34. D.D.Klemm, R.Klemm, A.Murr, Gold of the Pharaohs - 6000 years of gold mining in Egypt and Nubia. Journal of African Earth Sciences V.2001,33, 643-659p..

35. V.V. Seredin, and S.Dai, Coal deposits as potential alternative sources for Landthanides and Ytterium.Int.Coal Geol.2012,76,253-289p.

36. P.Boulvais,G.Ruffet, J.Comichertand M.Mermet,Cretaceous albitization and dequartzification of Hercynian peraluminous granite in Salvezines Massif (French Pyrenees) Lithio., 2007, 93, 89-106p.

37. M. Cathelineau, and P.Holliger,Polyphase metallogenesis of hydrothermal uranium veins from the southern amoricon massif ,France. Proc. Int. Mtg.Nancy, 1987,212-217p.

38. P.R.Simpsons, G.CBrown,J. Plantand D.Osthle,Uranium mineralization and granitic magmatism in the British Isles.Phil.Trans.Roy.Soc.London,1979,219A,385-412p.

39. M.Pagel, The mineralogy and geochemistry of uranium, thorium and rare elements in two radioactive granites of Vosages, France, Min, Mag.,1982, 46/339: 149-161p.

40. M.A.Zakrewski, W.J.Lustenhouwer, H.I. Nugteren, and C.T.,Williams, Rare earth minerals zirconlite-(y) and allanite-(ce) and associated minerals from Kberg mine, Bergslagen, Sweden.Mineral Mag.1992, 56,27-35p.

\section{* Corresponding Author: Mohamed El-Ahmady Ibrahim}

Nuclear Materials Authority, P.O. Box: 530, Maadi, Cairo, Egypt 